\section{Estudo \\ Ecibate}

em CAStão

Plamejamento
Revista Estudo \& Debate, Lajeado, v. 28, n. 3, 2021. ISSN 1983-036X

DOI: http://dx.doi.org/10.22410/issn.1983-036X.v28i3a2021.2773

\title{
RESÍDUOS SÓLIDOS URBANOS (RSU): PERCEPÇÃO AMBIENTAL DOS MORADORES DO BAIRRO MARACANÁ, BARRA DO BUGRES - MT
}

\author{
Diego Matos dos Santos ${ }^{1}$, Leandro José de Oliveira ${ }^{2}$, Ana Paula Silva de Andrade ${ }^{3}$, \\ Carlos Rezende de Pádua Junior ${ }^{4}$, Sônia Aparecida Beato Ximenes de Melo ${ }^{5}$
}

\begin{abstract}
Resumo: O presente trabalho foi desenvolvido com a perspectiva de investigar a forma como os moradores e a administração pública da cidade de Barra do Bugres-MT tratam os resíduos sólidos urbanos, pois questões relacionadas aos problemas ambientais vem ganhando destaque na sociedade contemporânea. Nesse contexto, este trabalho objetivou analisar a percepção ambiental dos moradores do bairro Maracaná no município de Barra do Bugres-MT, em relaçáo aos Resíduos Sólidos Urbanos (RSU). A pesquisa foi estruturada de forma qualiquantitativa, tendo como instrumento de coleta de dados a aplicaçáo de questionários semiestruturados. $\mathrm{O}$ período de aplicaçáo dos questionários ocorreu entre os meses de abril e maio de 2020. No total foram aplicados a quantia de 117 questionários. Os resultados identificaram que 70,09\% dos entrevistados acreditam que o poder público é responsável por coletar os resíduos sólidos urbanos, porém, 61,54\% afirmam que é por falta de educação e/ou zelo dos moradores que os resíduos são jogados em lugares inapropriados. Para 51,28\% dos respondentes a melhor solução para evitar os danos ambientais seria a fiscalização e multa. Nesse cenário, 52,99\% dos respondentes relataram que o poder público poderia fazer mais pela cidade referente a questáo ambiental, pois, 64,96\% diz que não existe nenhuma política ou projeto para os RSU. O estudo revelou que na cidade não existe coleta seletiva, assim, é importante que o poder público desenvolva projetos como Ecopontos, programas e açóes de Educação Ambiental que promovam à adequaçáo dos procedimentos de coleta e destinação dos RSU.
\end{abstract}

Palavras-chave: Gestão dos Resíduos Sólidos. Políticas Públicas. Educação Ambiental.

1 Bacharel em Ciências Contábeis pela Universidade do Estado de Mato Grosso (UNEMAT). E-mail: matosdiego987@gmail.com

2 Mestre em Agronegócios e Desenvolvimento Regional pela Universidade Federal de Mato Grosso (UFMT). E- mail: leandrogtaune@gmail.com

3 Mestre em Ambiente e Sistemas de Produção Agrícola pela Universidade do Estado de Mato Grosso (UNEMAT). E-mail: anapsakm@hotmail.com

4 Mestre em Engenharia Elétrica pela Universidade Estadual Paulista “Júlio de Mesquita Filho” (UNESP Ilha Solteira-SP). E-mail: carlos.junior@unemat.br

5 Mestre em Ambiente e Sistemas de Produção Agrícola pela Universidade do Estado de Mato Grosso (UNEMAT). E-mail: msc.soniaximenes@gmail.com 


\title{
URBAN SOLID WASTE (USW): ENVIRONMENTAL PERCEPTION OF RESIDENTS OF THE MARACANÁ DISTRICT, BARRA DO BUGRES - MT
}

\begin{abstract}
The present work was developed with the perspective of discovering how the residents and the public administration of the city of Barra do Bugres-MT treat urban solid waste, because, in the past and especially nowadays, the problems and debates surrounding the urban solid waste issue has been constant. In this context, this study aimed to analyze the environmental perception of residents of the Maracana neighborhood in the municipality of Barra do Bugres-MT, in relation to Urban Solid Waste (USW). The research was structured in a qualitative and quantitative way, using semi-structured questionnaires as a data collection instrument. The period of application of the questionnaires was carried out in the year 2020 between the months of April and May, totaling 117 questionnaires were applied. According to the results, it was identified that $70.09 \%$ of respondents believe that the government is responsible for collecting urban solid waste, however, $61.54 \%$ claim that it is for lack of education that waste is thrown in inappropriate places, and with that $51.28 \%$ believe that the best solution is inspection and fines, however, $52.99 \%$ say that the government could do more for the city regarding the environmental issue, since $64.96 \%$ say that there is no no policy and project for MSW. The study identified that there is no selective collection in the city, thus, it is important that the government develop projects such as Ecopoints, Environmental Education programs and actions that promote the adequacy of collection procedures and disposal of MSW.
\end{abstract}

Keywords: Solid Waste Management. Public Policies. Environmental Education.

\section{INTRODUÇÁO}

A dinâmica de evolução das cidades se relaciona ao desenvolvimento econômico e tecnológico, ao aumento populacional e ao nível de padrão de consumo da população, diretamente relacionado à produção de resíduos, cuja destinação é uma das grandes questốes ambientais atuais, devido à variedade e volume de materiais e escassez de áreas adequadas para sua deposição (HEGEL; CORNÉLIO, 2013; LEME, 2009).

A insuficiência de procedimentos de destinação correta favorecem o descarte em lugares inadequados, o que acarreta diversas alteraçóes de ordem ambiental, de saúde e social, evidenciando a ausência de uma gestáo eficiente (SOARES, 2012), que aliada à falta de recursos dos municípios para custear os processos de gerenciamento adequado (AGÊNCIA BRASIL 2019), incorre num dos motivos para o grande percentual de Resíduos Sólidos Urbanos não tratados.

No Brasil, em 2011, apenas 33\% das cidades tinham destino adequado para os resíduos sólidos gerados em seu território, sendo que na regiáo nordeste $89,3 \%$ das cidades ainda adota a disposição a céu aberto - lixôes - como destino final para seus resíduos (IBGE, 2010). Considerando que todo resíduo sólido é originado de algum processo produtivo e necessita destinação, a reciclagem ganha destaque por oportunizar sua reintrodução na cadeia de consumo como matéria-prima em um novo processo, mas que ainda é uma prática deficitária no Brasil (AGÊNCIA BRASIL, 2019).

Tendo em vista esse cenário, foi regulamentada a Política Nacional de Resíduos Sólidos (PNRS) pela Lei Federal $n^{\circ}$ 12.305/10, que estabelece um conjunto de diretrizes para adequaçáo do tratamento dos RSU, objetivando reduzir seu direcionamento para 
aterros/lixões e que estabelece vínculo entre os planos de resíduos sólidos e os planos de saneamento básico, em relação à limpeza urbana e ao manejo dos RSU.

Esses dois últimos instrumentos são contemplados no Plano Nacional de Saneamento Básico (PLANSAB), que engloba as atividades, infraestruturas e instalaçóes operacionais de coleta, transporte, transbordo, tratamento e disposição final do lixo doméstico e do lixo originário da varrição e limpeza de logradouros e vias públicas e que determina que até 2033 seja universalizado o acesso ao saneamento básico (LOPES, 2016; AGÊNCIA BRASIL, 2019).

Nesse contexto, Cazaroto (2012) pontua que a melhoria no meio ambiente advém principalmente de mudanças no comportamento, valores e condutas do ser humano, sendo essencial a implementação de um processo de educação que objetive trabalhar a consciência e percepção sensorial da realidade pelos indivíduos, enquanto Leme (2009) reforça que o estudo comportamental dos indivíduos pode contribuir para a formulação de estratégias e efetivação de programas para o tratamento dos RSU.

Estudos sobre percepção ambiental se justificam por contribuírem para a investigação das perspectivas de cada indivíduo por meio da análise de conhecimento, valores e opinióes, considerando que cada um percebe e se relaciona de forma diferente com o ambiente no qual está inserido (SUESS et al. 2013).

Dessa forma, a pesquisa buscou discorrer sobre a questão dos resíduos sólidos a partir da análise da percepção dos moradores do Bairro Maracaná no município de Barra do Bugres estado de Mato Grosso com objetivos específicos de averiguar o perfil socioeconômico, o nível de conhecimento dos moradores acerca dos RSU, verificar a percepção econômica dos moradores em relação aos RSU, e apontar as principais demandas no entendimento dos moradores em relação às açóes executadas pelo poder público local acerca dos RSU.

\section{REFERENCIAL TEÓRICO}

\subsection{Gestão dos Resíduos Sólidos Urbanos}

Conforme NBR 10.004 (Associação Brasileira de Normas Técnicas - ABNT, 2004) os Resíduos Sólidos Urbanos - RSU, denominados também como lixo urbano, são resultantes da atividade doméstica e comercial dos centros urbanos. A Política Nacional de Resíduos Sólidos (PNRS), criada pela Lei Federal no 12.305/2010, os define como todo material, substância, objeto ou bem descartado resultante de atividades humanas em sociedade e sua composição depende da situação socioeconômica e das condições e hábitos de vida de cada consumidor.

De acordo com o Panorama dos Resíduos Sólidos no Brasil, da Associação Brasileira de Empresas de Limpeza Pública e Resíduos Especiais (ABRELPE), em 2016, a geração de RSU no país foi de 78,3 milhóes de toneladas. O brasileiro produziu, em média, 1,04 $\mathrm{kg}$ de lixo/dia, representando 214.405 toneladas diárias, que podem ser tratadas com um conjunto de alternativas como processamento dos orgânicos, reciclagem, produção de biogás ou combustível e produção de energia elétrica. 
Historicamente, a gestão dos RSU foi por bastante tempo realizada pelas prefeituras de forma que sua disposição final ocorria em lixóes a céu aberto ou enterrados e queimados, sem qualquer controle ambiental e de saúde pública. Resíduos industriais, hospitalares e urbanos eram depositados no mesmo local, sem qualquer tipo de tratamento técnico específico (TROTTA, 2011).

Em vista disso, as cidades têm buscado aplicar diversas tecnologias, políticas e comportamentos para o controle dos seus resíduos e para implementar meios de reutilizaçáo dos mesmos, com embasamento legal, observando os aspectos sociais de proteçáo ao meio ambiente, a saúde pública e aos recursos financeiros disponíveis (BERTICELLI; PANDOLFO; KORF, 2017).

As decisóes tomadas na gestáo de RSU devem ser sustentadas em estruturas de orientação essenciais como a redução de resíduos, reutilização, reciclagem, recuperação de energia e disposição final em lugar adequado e a gestão integrada, que representam um acervo de princípios de gerenciamento ambiental economicamente apropriados (BERTICELLI; PANDOLFO; KORF, 2017).

\subsection{O Papel das Políticas Públicas no Contexto dos RSU}

As Políticas Públicas (PP) são por definição "um conjunto de programas, ações e decisóes tomadas pelos governos nacional, estadual ou municipal que afetam a todos os cidadãos, de todas as escolaridades, independente de sexo, cor, religião ou classe social" (FIOCRUZ, 2018).

Para Melazzo et al. (2003), uma PP pode ser entendida como um conjunto de açóes e também omissóes que manifestam uma determinada modalidade de intervençấo do Estado em relação a uma questão de interesse e mobilização de outros setores.

No Brasil, compete à União o ordenamento da matéria, aos municípios e ao Distrito Federal o estabelecimento de regras específicas. A Política Nacional de Resíduos Sólidos (PNSR) orienta pontos importantes para o avanço no setor de RSU, como um corpo técnico qualificado, agentes da sociedade civil engajados com a problemática e ainda possibilidades econômicas para o crescimento da indústria de reciclagem, mas que necessita efetivação das ações, já que a política em si dá apenas diretrizes para sua elaboração.

No município de Barra do Bugres-MT, o plano de saneamento básico é regulamentado pela Lei Federal no 11.445/2007, que esclarece as atividades de planejamento, prestação, regulamentação e fiscalizaçáo dos serviços de saneamento, sendo responsável pela limpeza urbana, manejo de resíduos sólidos, drenagem e o manejo de água pluviais (LIMA; FILHO; MOURA, 2017).

Atualmente, a prefeitura do município não oferece coleta seletiva, apenas disponibiliza a coleta domiciliar três vezes por semana, utilizando lixão para o descarte dos resíduos, embora exista a intenção de implementação de um aterro sanitário e o planejamento de montar uma cooperativa de coleta seletiva por alguns catadores independentes, cujo projeto ainda não foi desenvolvido. No presente momento, essas são as únicas alternativas vislumbradas pelo município (RABÊLO et al., 2013). 
Diante disso, até o município elaborar um plano de gerenciamento de resíduos poderia fazer uso da gestão dos Resíduos Sólidos Urbanos em Ecopontos. Os Ecopontos são locais que recebem resíduos como podas de árvores, descartes de entulhos, móveis inutilizáveis, entre outros. Os Ecopontos possibilitam acesso para a população realizar o descarte de forma sustentável, e não através de bolsões, que são formas sem controle, no qual as pessoas colocam lixo de forma clandestina no meio da rua (LUPPI; SILVA; ARANTES, 2019).

Embora a PNRS não faça referência literalmente aos Ecopontos, esta estimula a cooperação técnica e financeira entre os setores público e privado para o desenvolvimento de pesquisas de novos produtos, métodos, processos e tecnologias de gestâo. Além disso, faz referência há vários outros instrumentos como o incentivo à criação e ao desenvolvimento de cooperativas ou de outras formas de associação de catadores de materiais reutilizáveis e recicláveis, a educação ambiental, a reciclagem, a reutilizaçáo, o tratamento de resíduos e disposiçáo final ambientalmente adequada de rejeitos, que parecem culminar com a necessidade de pontos de apoio capazes de coordenar vários dos instrumentos propostos por esta política (VERAS JUNIOR et al., 2019).

Zanta e Ferreira (2003) argumentam que, sendo a gestáo dos RSU uma complexidade ambiental com impactos diretos na qualidade de vida das pessoas, essa abordagem propicia uma oportunidade para obter o comprometimento da populaçáo com a sustentabilidade, fomentando a mudança de hábitos de consumo, tanto por repensar as aquisiçóes quanto pelo reaproveitamento e reuso dos materiais.

Nesse sentido, Barbosa et al. (2010) aponta a reciclagem como um ponto convergente dos agentes transformadores, a saber a população e os gestores públicos, em relação ao tratamento dos RSU e que pode integrar grupos de todas as esferas sociais e fazer parte de políticas públicas eficientes, especialmente quando aliada à Educação Ambiental, pois atuam no incentivo à mudança de atitude e sensibilização da população.

A Educação Ambiental (EA) nasceu da necessidade de modelar a postura dos seres humanos para com o meio ambiente e foi iniciada pelos movimentos ecológicos e posteriormente comtemplada com a publicação da Lei Federal 9.795, de 27/4/1999, que institui a Política Nacional de Educação Ambiental e dá outras medidas.

Além disso, uma ferramenta importante para o entendimento e implementação de açóes coletivas de sensibilização é a percepçáo ambiental, que pode ser definida como o resultado da interação do indivíduo com o meio e suas constantes transformaçóes, através da qual se atribui valores e importâncias diferenciadas em relaçáo ao local em que está inserido e conduz a um novo olhar sobre o presente e futuro, favorecendo a introduçáo de novas formas de proceder e tratar o meio ambiente (FERNANDES et al. 2004; MACEDO, 2000).

\section{METODOLOGIA}

\section{1 Área de estudo}

O bairro Maracaná, local de desenvolvimento da pesquisa, possui área total de aproximadamente $11,44 \mathrm{~km}^{2}\left(4,42 \mathrm{mi}^{2}\right)$ (IBGE, 2019) e localiza-se no município de Barra 
do Bugres (Figura 1), regiāo Centro-Oeste do Brasil, no estado de Mato Grosso, a 150 quilômetros da capital Cuiabá. $\mathrm{O}$ município possui área de $7.186,78 \mathrm{~km}^{2}$ e sua população foi estimada em 34.966 habitantes em 2019.

Figura 1 - Localização de Barra do Bugres - MT.

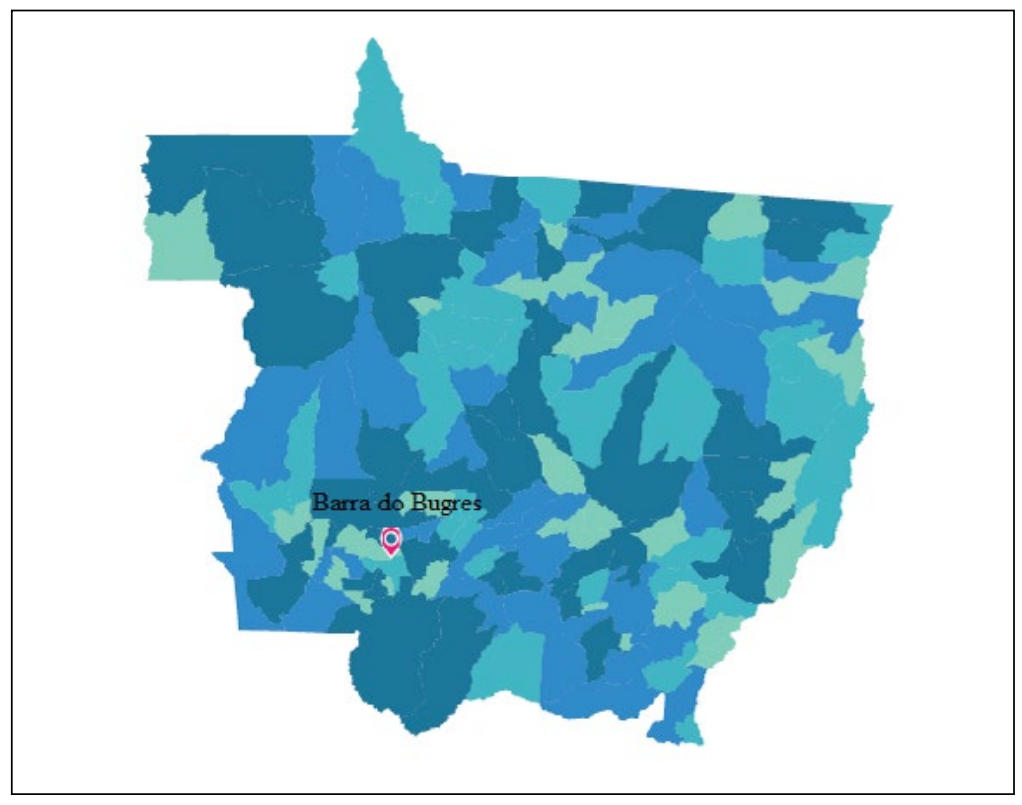

Fonte: IBGE (2019).

Segundo a Secretaria Municipal de Obras, Viação e Serviços Públicos de Barra do Bugres, as atividades econômicas do município estão relacionadas à agricultura, como canade-açúcar, a pecuária e ao comércio agroindustrial, abrigando uma usina de álcool e açúcar, que traz, em média 2 mil trabalhadores sazonais vindos da região Nordeste do país, segundo seus administradores. $\mathrm{O}$ comércio e os domićlios geram um montante equivalente a 14 toneladas diárias de RSU, que segundo Magalhães e Werle (2009) são uma das principais fontes de contaminação ambiental do município.

\subsection{Caracterizaçáo da pesquisa}

A pesquisa caracteriza-se como descritiva e fundamenta-se em uma abordagem qualiquantitativa, pautada no levantamento bibliográfico e aplicação de questionários com o intuito de analisar a percepçáo ambiental dos moradores do bairro Maracanã, em Barra do Bugres-MT. A pesquisa descritiva busca delinear as características de um fenômeno em pesquisa, considerando como objeto uma situação específica, um grupo ou indivíduo (RICHARDSON et al., 2007; GIL, 2010).

A abordagem quantitativa é guiada pelo modelo de investigação conhecido como dedutivo, que abrange a questáo problema e a conjectura, testadas pela observaçáo e experimentação e valendo-se de técnicas e procedimentos estatísticos para embasar 
as análises, enquanto a abordagem qualitativa, em contrapartida, é mais dialética e visa entender o significado dos fenômenos e processos sociais, levando em consideração as motivaçóes, crenças, valores, representaçóes sociais e econômicas, ou seja, o foco principal é a compreensão interpretativa da ação social (SILVA, 2010).

Como procedimento de coleta de dados, fez-se o uso de levantamento bibliográfico, em formas de artigos científicos, livros, teses e dissertaçóes, com a finalidade de inteirar o pesquisador sobre o que foi escrito sobre determinado assunto, procedimento este que, segundo Marconi e Lakatos (2017) conceder reforço na análise das pesquisas e organização de suas informaçóes.

Segundo Gil (2010), para definição da quantidade de questionários aplicados, o cálculo da amostra será feito conforme a equação a seguir:

$$
n=\frac{\sigma^{2} \cdot \mathrm{p} \cdot \mathrm{q} \cdot \mathrm{N}}{\mathrm{e}^{2} \cdot(\mathrm{N}-1)+\sigma^{2} \cdot \mathrm{p} \cdot \mathrm{q}}
$$

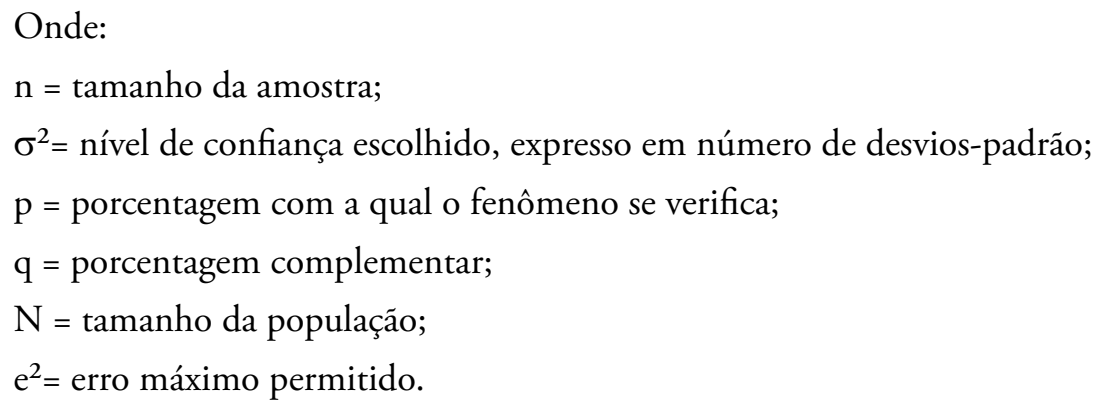

Logo, para uma população de 4.548 habitantes $(\mathrm{N}=4.548) ; \sigma^{2}=$ intervalo de confiança, considerando um nível de confiança de $92 \%$; $p=$ representa a estimativa da proporção populacional, neste caso, $50 \%$; q= sendo a parcela da populaçáo desconsiderada $(q=100-p=50 \%) ; e^{2}=$ representa o erro aleatório estimado em $8 \%$, obtém-se uma amostra (n) com tamanho equivalente a 117 pessoas que foram entrevistadas.

$\mathrm{O}$ instrumento de coleta de dados consistiu na elaboração de um questionário semiestruturado que abordou quatro aspectos: a) perfil socioeconômico; b) percepção acerca dos RSU; c) responsabilidade do poder público, e d) percepção econômica em relação aos RSU.

Os questionários no bairro foram aplicados em 29 ruas, com distribuição de 3 questionários por rua e somente em uma rua foi distribuído um questionário a mais. Buscou-se fazer a distribuição em ruas e locais bem distintos do bairro, com a intenção de ter respondentes de cada localização, sem ser próximo um do outro, visando evitar erros estatísticos em relação aos moradores que representaram o universo da população local. Após o recolhimento dos questionários, os dados foram organizados em tabelas, quadros e gráficos. O tratamento das variáveis coletadas foi submetido a análise estatística com o uso do Software EXCEL. 


\section{RESULTADOS E DISCUSSÃO}

A apresentação dos resultados obtidos e sua discussão foi dividida em subtópicos, sendo o primeiro o perfil socioeconômico, para caracterização do público respondente. A segunda sessão trata da percepçáo dos moradores com relação aos RSU, a terceira sessão acerca da responsabilidade do poder público e por fim, a quarta sessão tratando da percepção econômica dos moradores em relação aos RSU.

\subsection{Perfil Socioeconômico dos Moradores do Bairro Maracanã}

De acordo com as informaçóes coletadas, a maioria dos entrevistados é do sexo feminino $(55,56 \%)$ e reside entre 0 a 10 anos no bairro, conforme Tabela 1 .

Tabela 1 - Tempo de residência no bairro.

\begin{tabular}{lcc}
\hline Categoria & Quantidade & $\mathbf{( \% )}$ \\
\hline 0 a 10 anos & 53 & $45,30 \%$ \\
11 a 20 anos & 32 & $27,35 \%$ \\
21 a 30 anos & 21 & $17,95 \%$ \\
31 a 40 anos & 9 & $7,69 \%$ \\
Superior a 41 anos & 2 & $1,71 \%$ \\
\hline TOTAL & $\mathbf{1 1 7}$ & $\mathbf{1 0 0 \%}$ \\
\hline
\end{tabular}

Fonte: Dados da pesquisa (2020).

O tempo de residência no bairro foi utilizado como indicador do vínculo temporal com o local e com base na Tabela 1, percebe-se que há uma porcentagem significativa de residentes antigos no bairro e tendo isso em vista, é válido ressaltar que muitas das respostas dos moradores também são baseadas pelo que veem no município como um todo.

A faixa etária foi dividida em categorias, pelas quais verificou-se que a idade dos respondentes variou entre 18 e 66 anos, conforme apresentado na Tabela 2.

Tabela 2 - Faixa etária de idade dos entrevistados.

\begin{tabular}{lcc}
\hline Categoria & Quantidade & (\%) \\
\hline 18 a 25 anos & 43 & $36,75 \%$ \\
26 a 35 anos & 31 & $26,50 \%$ \\
36 a 51 anos & 27 & $23,08 \%$ \\
52 a 65 anos & 11 & $9,40 \%$ \\
Superior a 66 anos & 5 & $4,27 \%$ \\
\hline TOTAL & $\mathbf{1 1 7}$ & $\mathbf{1 0 0 \%}$ \\
\hline
\end{tabular}

Fonte: Dados da pesquisa (2020). 
$\mathrm{Na}$ disposição dos entrevistados pela faixa etária, identificou-se que $36,75 \%$ dos respondentes sáo jovens de 18 a 25 anos, com uma margem de respondentes adultos de 36 a 51 anos correspondente a 23,08\% e também pessoas de 52 a 65 anos representando $9,40 \%$, constituindo uma amostra de respondentes de diversas idades. $\mathrm{O}$ valor averiguado da renda familiar dos entrevistados é apresentado na Tabela 3.

Tabela 3 - Renda familiar.

\begin{tabular}{lcc}
\hline Categoria & Quantidade & $\mathbf{( \% )}$ \\
\hline Até 2 salários mínimos & 46 & $39,32 \%$ \\
Até 1 salário mínimo & 39 & $33,33 \%$ \\
Até 3 salários mínimos & 25 & $21,37 \%$ \\
Acima de 3 salários mínimos & 7 & $5,98 \%$ \\
\hline TOTAL & $\mathbf{1 1 7}$ & $\mathbf{1 0 0 \%}$ \\
\hline
\end{tabular}

Fonte: Dados da Pesquisa (2020).

Conforme as informaçóes coletadas, $39,32 \%$ dos respondentes tem renda de dois salários mínimo, contra 5,98\% com renda acima de 3 salários mínimos. Como a maior renda favorece maior consumo, assume-se que quanto maior a renda e o número de moradores por residência (Tabela 4) maior será o volume de resíduos descartados (QUERINO, 2015). No entanto, deve-se atentar que essa variável depende do nível de conhecimento e sensibilizaçáo individual em relação às práticas de consumo e descarte.

Tabela 4 - Quantas pessoas residem na casa.

\begin{tabular}{lcc}
\hline Categoria & Quantidade & $\mathbf{( \% )}$ \\
\hline 3 a 4 pessoas & 74 & $63,25 \%$ \\
1 a 2 pessoas & 24 & $20,51 \%$ \\
5 a 6 pessoas & 18 & $15,38 \%$ \\
Mais de 6 pessoas & 1 & $0,85 \%$ \\
\hline TOTAL & $\mathbf{1 1 7}$ & $100 \%$ \\
\hline
\end{tabular}

Fonte: Dados da Pesquisa (2020).

O nível de escolaridade dos respondentes foi verificado (Tabela 5) em virtude de que por meio da escola é que mais comumente as pessoas são apresentadas às práticas de Educação Ambiental (QUERINO, 2015). 
Tabela 5 - Nível de Escolaridade.

\begin{tabular}{lcc}
\hline Categoria & Quantidade & $\mathbf{( \% )}$ \\
\hline Ensino médio completo & 41 & $35,04 \%$ \\
Ensino médio incompleto & 25 & $21,37 \%$ \\
Ensino fundamental incompleto & 18 & $15,38 \%$ \\
Ensino superior incompleto & 18 & $15,38 \%$ \\
Ensino superior completo & 7 & $5,98 \%$ \\
Não alfabetizado & 5 & $4,27 \%$ \\
Ensino fundamental completo & 3 & $2,56 \%$ \\
\hline TOTAL & $\mathbf{1 1 7}$ & $\mathbf{1 0 0} \%$ \\
\hline
\end{tabular}

Fonte: Dados da Pesquisa (2020).

De acordo com os dados coletados, apenas 4,27\% dos respondentes não são alfabetizados, declararam um mínimo conhecimento de leitura, o que permitiu a participação na entrevista.

\subsection{Percepção dos Moradores com Relação aos Resíduos Sólidos Urbanos}

Entre os respondentes, $82,91 \%$ souberam identificar os materiais que são RSU, contra $17,09 \%$ que não souberam. Esse resultado é semelhante ao estudo realizado por Querino (2015) no município de São Sebastiāo de Lagoa de Roça, no qual 82\% dos seus entrevistados souberam responder corretamente.

Ao serem questionados sobre o que consideram RSU, os respondentes apontaram garrafas PET em primeiro lugar (17,59\%) seguidos pelas latas de refrigerante $(17,04 \%)$. A categoria "Outros" incluiu os demais itens citados por eles como resíduos, mas que foram menos citados e que representaram (10,74\%), conforme Tabela 6.

Tabela 6 - O que você considera como resíduo.

\begin{tabular}{lcc}
\hline Categoria & Quantidade & $\mathbf{( \% )}$ \\
\hline Garrafa Pet & 95 & $17,59 \%$ \\
Lata de Refrigerante & 92 & $17,04 \%$ \\
Pneu & 82 & $15,19 \%$ \\
Vidro & 77 & $14,26 \%$ \\
Plástico & 73 & $13,52 \%$ \\
Papel & 63 & $11,67 \%$ \\
Outros & 58 & $10,74 \%$ \\
\hline TOTAL & 540 & $100 \%$ \\
\hline
\end{tabular}

Fonte: Dados da pesquisa (2020). 
Os resultados demonstram que os moradores puderam identificar o que são os RSU, no entanto, no estudo realizado por Morais et al., (2018), no município vizinho de Tangará da Serra - MT os resultados apontaram uma listagem diferente de materiais listados pelos moradores. Portanto, nota-se pontos de vista diferente, mas que convergem em comparação com outros estudos no que tange a natureza dos materiais citados.

Em relação ao que fazem com o lixo produzido em suas residências, (61,54\%) dos moradores relataram que o amontoa em sacos, (19,05\%) participam da coleta seletiva, e $(8,73 \%)$ reaproveita o lixo orgânico. Nota-se o problema através dessa questão, pelo fato, de que a maioria dos respondentes não faz a separação do que pode ser aproveitado e reciclado por não existir essa opção no município.

Nesse contexto, quando questionado aos respondentes o que é reciclagem (Tabela 7), $(42,74 \%)$ dos moradores consideram o processo industrial ou artesanal que converte o lixo descartado em um produto semelhante ao inicial, $(21,37 \%)$ o ato de separar o lixo em casa e $(17,09 \%)$ o processo para diminuir os impactos pelo lixo no aquecimento global.

Tabela 7 - O que é Reciclagem.

\begin{tabular}{lcc}
\hline Categoria & Quantidade & (\%) \\
\hline $\begin{array}{l}\text { É um processo industrial ou artesanal que converte o lixo descartado } \\
\text { em um produto semelhante ao inicial }\end{array}$ & 50 & $42,74 \%$ \\
$\begin{array}{l}\text { É separar o lixo em casa } \\
\text { É um processo para diminuir os impactos pelo lixo no aquecimento }\end{array}$ & 25 & $21,37 \%$ \\
global & 20 & $17,09 \%$ \\
É um processo para reduzir a geração de lixo & 12 & $10,26 \%$ \\
Não soube & 7 & $5,98 \%$ \\
Não quis responder & 3 & $2,56 \%$ \\
\hline TOTAL & $\mathbf{1 1 7}$ & $\mathbf{1 0 0 \%}$ \\
\hline
\end{tabular}

Fonte: Dados da Pesquisa (2020).

Embora a maioria tenha apontado corretamente o que é o processo de reciclagem, uma parte significativa apontou para a separação de resíduos, que é apenas o primeiro passo, uma vez que depois ele deve ser encaminhado para o processo de industrializaçáo e para um de seus efeitos, que é diminuir as emissóes de gases gerados pelos RSU que provocam aquecimento global.

Barros (2013) destaca que é importante saber o significado de reciclagem, para que eles possam ter atitudes que ajude a manter o local limpo, separando o lixo, participando da coleta seletiva, reaproveitando os resíduos orgânicos são pequenas atitudes que ajudam a manter o local organizado e limpo.

Ao serem questionados se os resíduos sólidos urbanos quando não gerenciados podem provocar doenças, $94,87 \%$ dos respondentes afirmam que sim e $77,78 \%$ dos respondentes concordam que as doenças aumentam devido ao acúmulo de lixo. Do total de respondentes, 
39,56\% apontaram a dengue como a principal doença seguido pela Zica e Chikungunya com $26,01 \%$ respectivamente (Figura 2).

Figura 2 - Quais doenças o descarte inadequado pode ocasionar.

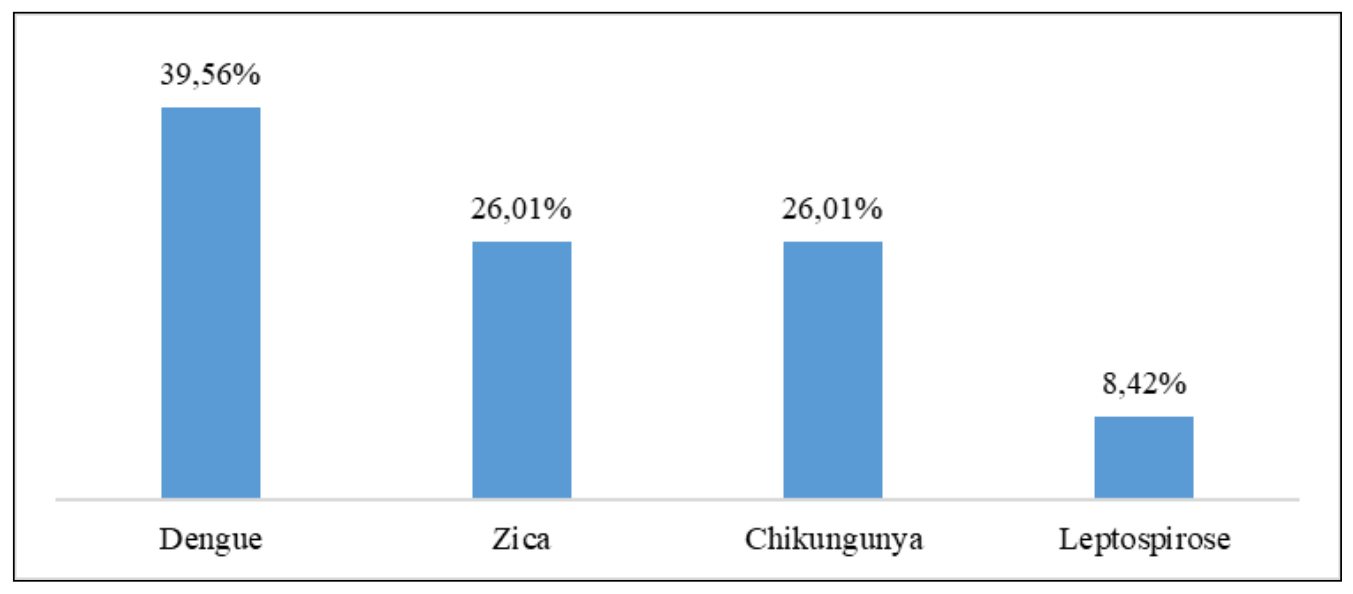

Fonte: Dados da Pesquisa (2020).

Sobre qual a destinação dos resíduos sólidos da cidade, $85,47 \%$ dos respondentes apontaram o lixão, 5,98\% reciclagem e aterro sanitário e 4,28\% afirmaram que estes vão para terrenos baldios. Aqui, a maioria apontou corretamente o destino dos RSU, porém, um percentual significativo afirmou que o destino era a reciclagem, que não existe no município, demonstrando que estes moradores não têm conhecimento do destino de seus resíduos e acreditam equivocadamente que os mesmos são reciclados.

A Figura 3 apresenta a placa de entrada do lixão da cidade de Barra do Bugres, condizendo com os resultados obtidos de que os RSU da cidade são jogados no lixão. 
Figura 3 - Entrada do Lixão Municipal da Cidade de Barra do Bugres.

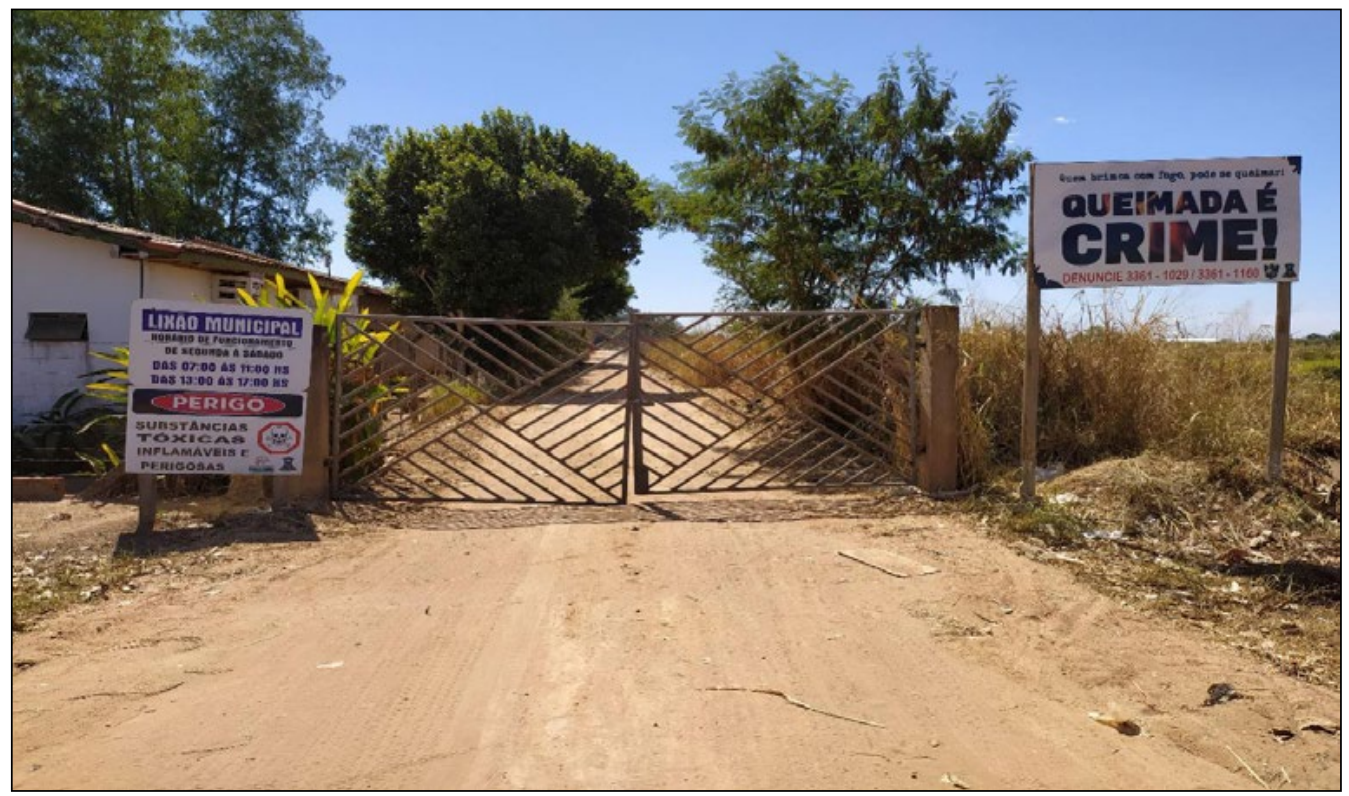

Fontes: Dados da pesquisa (2020).

Nas Figuras 4 e 5 é possível visualizar grande variedade de RSU como vidros, borracha pneu, aparelhos eletrônicos, papelăo, entre outros resíduos descartados no lixão municipal da cidade de Barra do Bugres. Ainda na Figura 5 observa-se uma coluna de fumaça se espalhando resultado de queimada nas proximidades do local, prática proibida pela Lei Federal no 9.605/1998, configurando crime ambiental, passível de penalidades e multas.

Contudo percebe-se imagens de um local totalmente abandonado, com grande nível de poluição, resíduos a céu aberto, sem nenhuma medida de proteção ao meio ambiente e consequentemente com a saúde pública. 
Figura 4 - Imagens de Resíduos Sólidos jogados no Lixão.

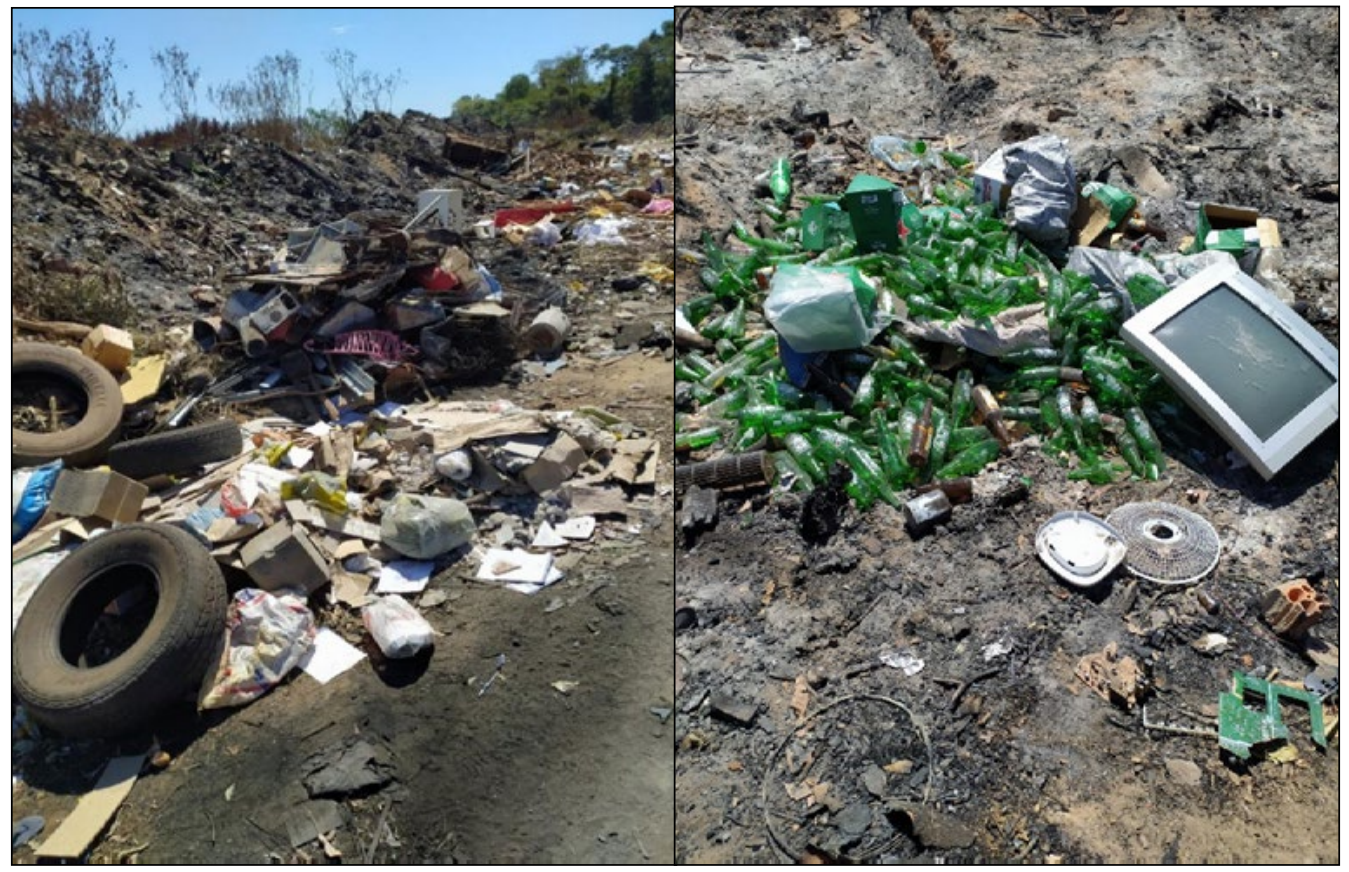

Fontes: Dados da pesquisa (2020).

Figura 5 - Imagens de Resíduos Sólidos jogados no Lixão.

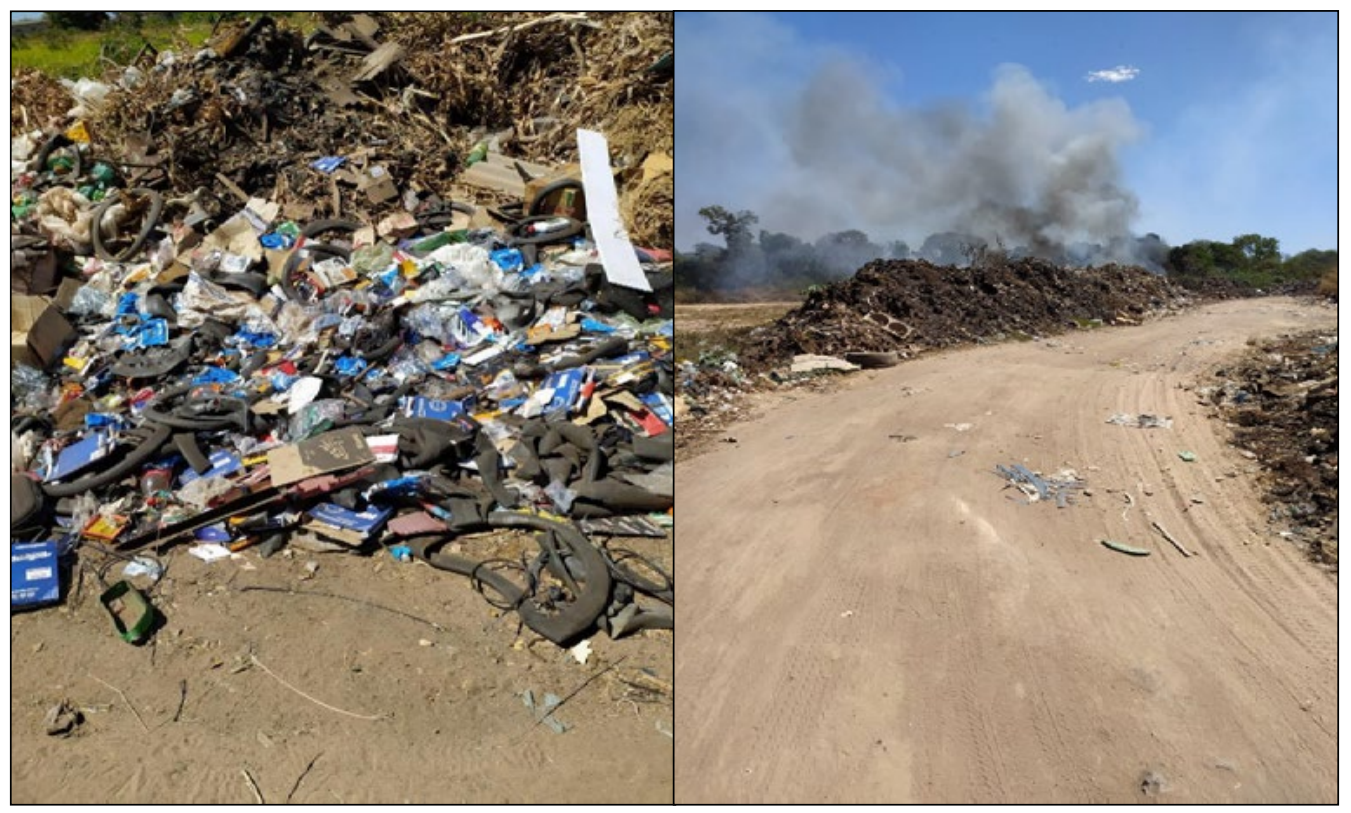

Fontes: Dados da pesquisa (2020). 
No local não há controle ou monitoramento dos resíduos depositados, fazendo com que resíduos domiciliares, comerciais, industriais e hospitalares de baixa e alta periculosidade se misturem e contaminem o solo através do chorume - líquido que escorre dos resíduos atraindo animais e aumentando as chances de proliferação de doenças prejudiciais à saúde humana.

Foi questionado aos moradores sobre qual seria o local correto para o descarte dos resíduos sólidos (Figura 6) e 43,59\% dos moradores responderam que é a reciclagem, $27,35 \%$ os lixōes e $18,80 \%$ que o mais correto é o aterro sanitário. Zani et al. (2019) tem resultado semelhante, onde os respondentes afirmaram que, o destino mais correto seja o aterro sanitário no entendimento de $(70,4 \%)$, aterro controlado $(19,7 \%)$ e os lixóes $(9,9 \%)$. Já Hempe e Nogueira (2012) identificaram que a alternativa menos viável é o lixão, que ainda domina $75 \%$ do descarte do RSU no Brasil.

Figura 6-Qual o mecanismo ambientalmente correto para destino final de RSU?

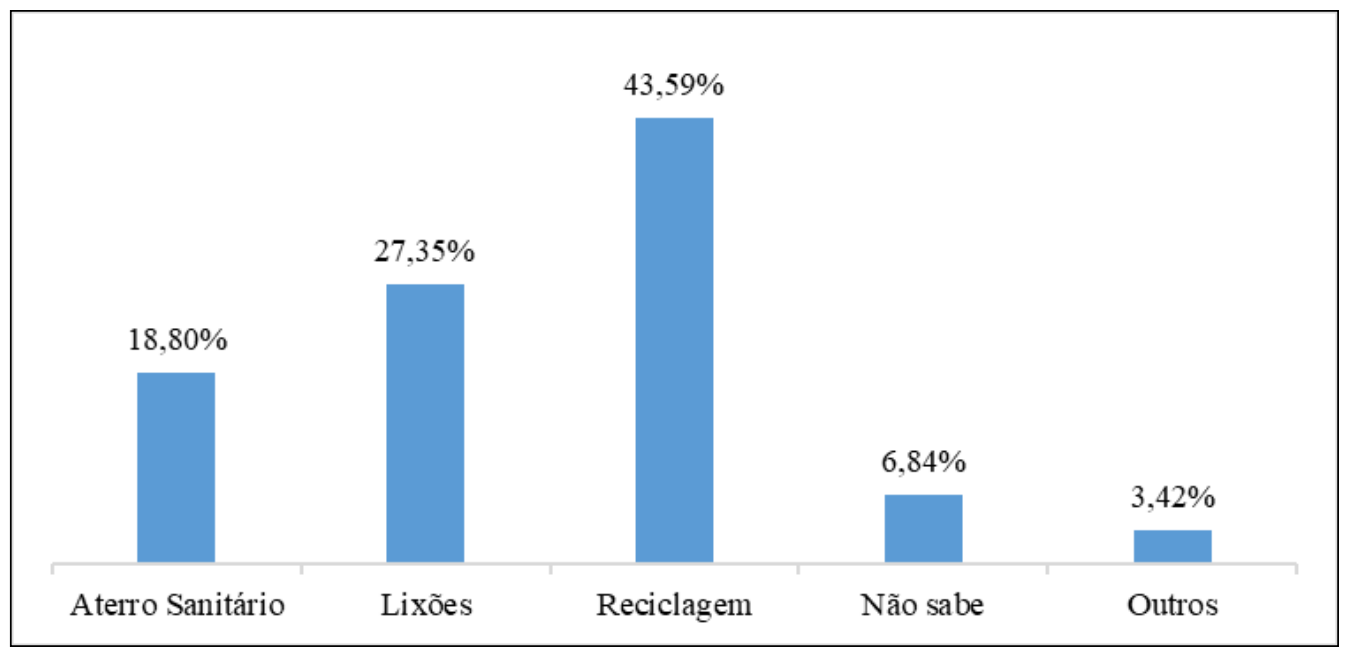

Fonte: Dados da Pesquisa (2020).

Nota-se que os moradores têm conhecimento sobre quais os locais corretos para descarte dos resíduos sólidos, sendo a reciclagem o destino mais indicado, já que possibilita o reaproveitamento dos materiais descartados, além da disposição em aterro sanitário, que ainda não existe no município.

Em relação aos resíduos descartados dentro do bairro, os mais citados são as garrafas $(19,63 \%)$, resto de construção $(18,95 \%)$, e pneus $(15,07 \%)$, um dos itens que mais gera problemas como o acúmulo de água parada, conforme Figura7. 
Figura 7 - Descarte inadequado em terrenos baldios.

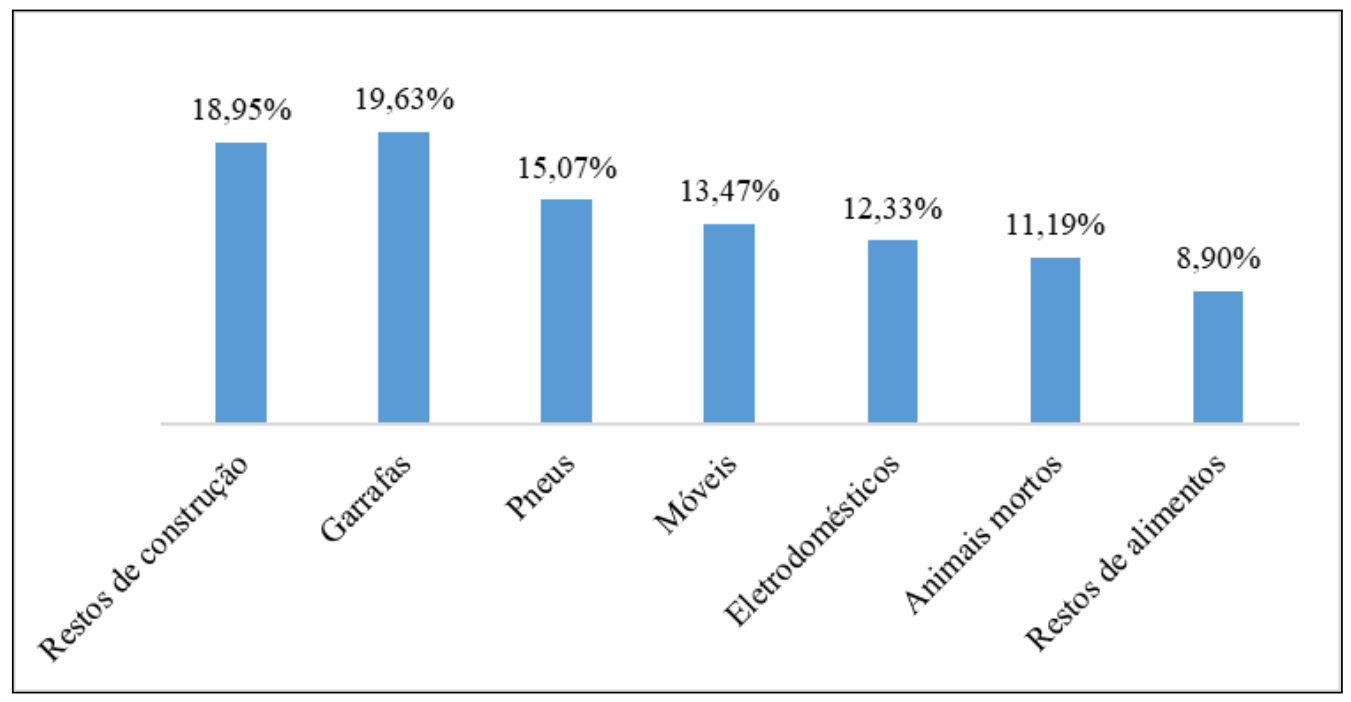

Fonte: Dados da Pesquisa (2020).

A Figura 8 retrata um terreno baldio localizado no bairro, nas proximidades do rio Paraguai, um dos principais rios de planície do Brasil e o elemento fisiográfico mais importante do Pantanal Mato-Grossense (ZANI et al., 2008; JUNK et al., 2006), com vários resíduos, que além de causar poluição visual, também impactam o solo, contaminando o rio e se tornando abrigo de animais, insetos e parasitas transmissores de doenças, colocando em perigo a saúde e a vida dos moradores.

Figura 8 - Imagens de RSU jogados em terreno baldio do bairro Maracanã.

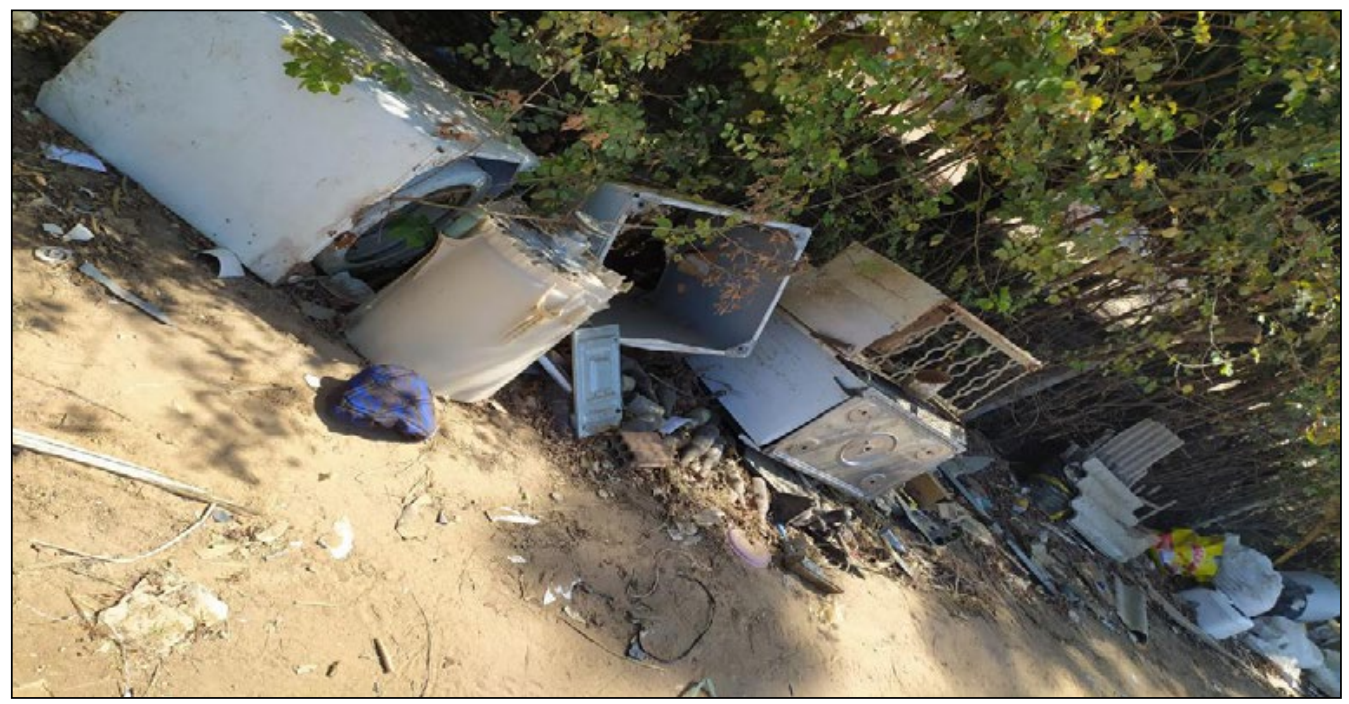

Fontes: Dados da pesquisa (2020). 
Quando questionado aos respondentes quais problemas ambientais são causados pelo descarte inadequado (Figura 9), os mesmos apontaram doenças $(37,28 \%)$, contaminação do solo e das águas (35,53\%), e poluição visual (27,19\%), que acabam por prejudicar a saúde e a beleza cênica do bairro, além de também produzirem mau cheiro.

Figura 9 - Problemas ambientais causados ao se jogar resíduos em locais inapropriados.

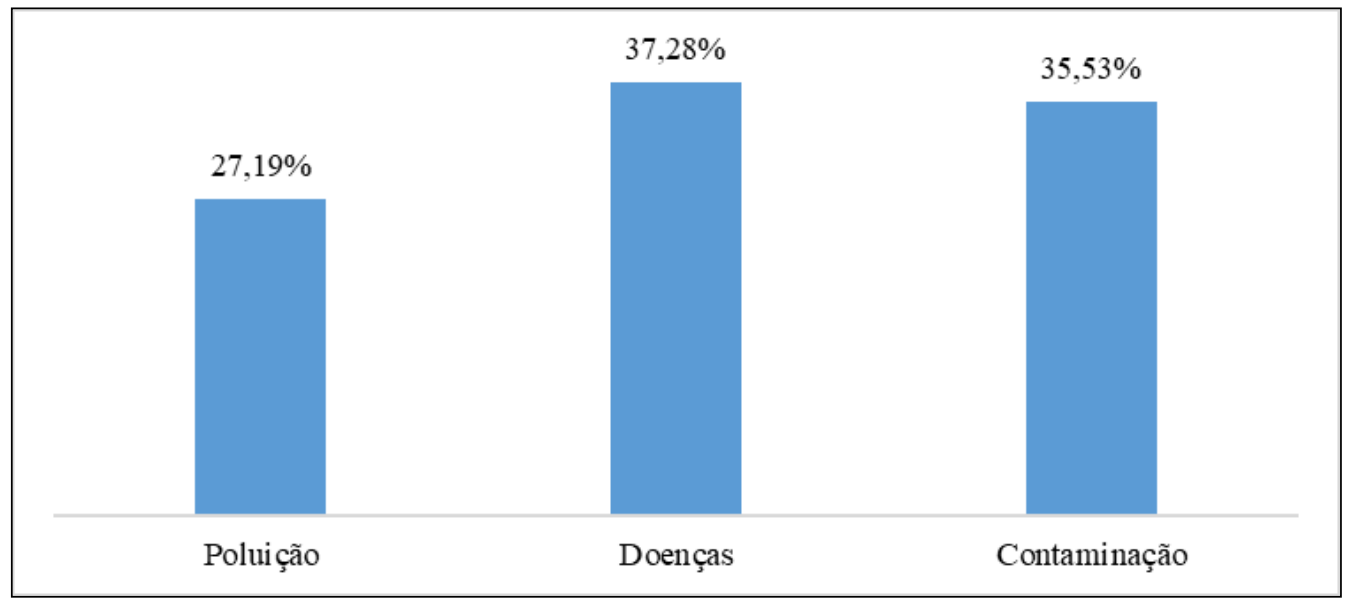

Fonte: Dados da Pesquisa (2020).

Quanto ao que leva os moradores do bairro a jogar os resíduos sólidos em lugares inapropriados (Figura 10), 61,54\% acredita que seja por falta de educação, 24,79\% por falta de lugar para descartar e $12,82 \%$ por falta de coleta dos materiais. Para a maioria, o descarte é feito pelos próprios moradores, que náo tem consciência dos problemas que esse procedimento causa ao bairro.

Figura 10 - O que leva os moradores a jogar resíduos em lugares inadequados.

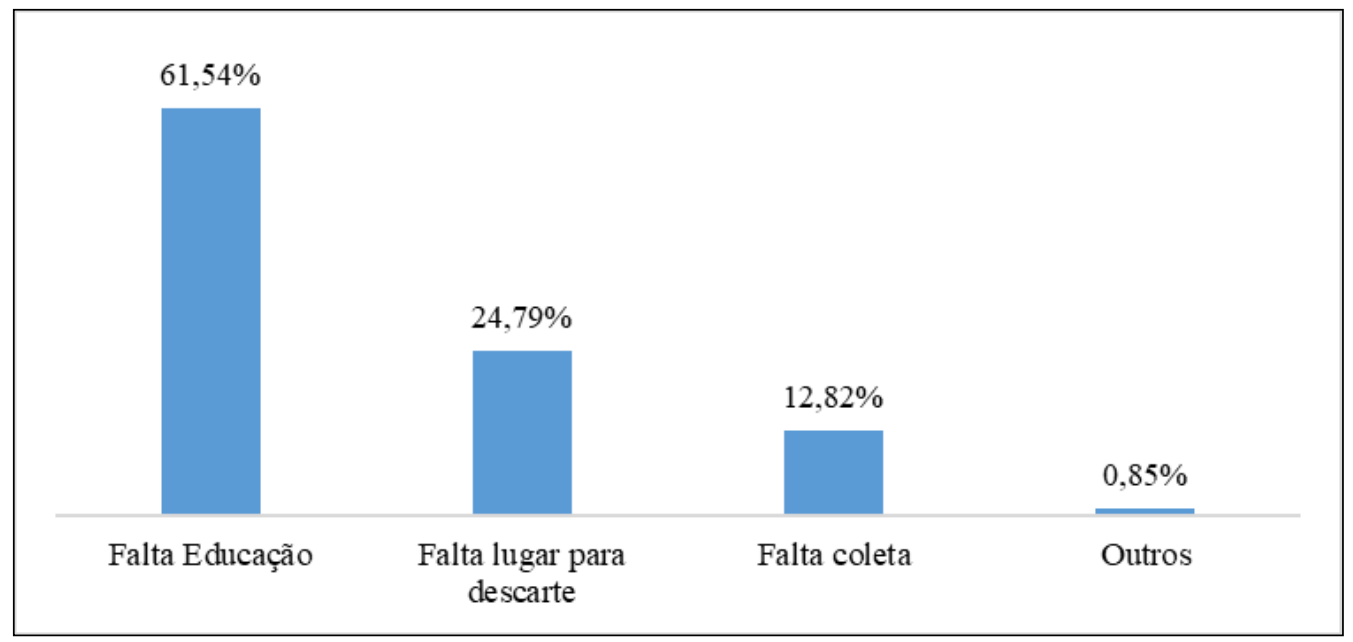

Fonte: Dados da Pesquisa (2020). 
Estudo realizado por Morais et al., (2018) no bairro Jardim Tarumã em Tangará da Serra - MT, apresentou resultado similar, no qual 72,13\% dos moradores afirmaram que o descarte inadequado é causado por falta de educaçáo e/ou falta de zelo, ou seja, a motivaçáo do descarte inadequado dos resíduos refere-se a falta de bom senso dos próprios moradores, outros $22,13 \%$ por falta de coleta e $5,74 \%$ por falta de lugar apropriado para o descarte.

Açóes de Educação Ambiental, que objetivem estimular o cuidado com o meio ambiente por meio de atitudes que sejam voltadas para sua conservação, podem ser uma das alternativas para diminuir ou eliminar o descarte inadequado.

Sobre quais problemas ambientais existem no bairro (Tabela 8), os moradores listaram os resíduos jogados na rua $(15,18 \%)$, em segundo lugar as queimadas $(12,68 \%)$, e em terceiro a poluição do ar $(12,47 \%)$, colocando a poluição como consequência das queimadas e ainda esgoto a céu aberto, gestão inapropriado dos resíduos, doenças, falta de água, entre outros.

Tabela 8 - Problemas ambientais citados que geram mais impactos no Bairro Maracaná.

\begin{tabular}{lcc}
\hline Categoria & Quantidade & $\mathbf{( \% )}$ \\
\hline Resíduos jogados na rua & 73 & $15,18 \%$ \\
Queimadas & 61 & $12,68 \%$ \\
Poluiçáo do ar & 60 & $12,47 \%$ \\
Esgoto a céu aberto & 48 & $9,98 \%$ \\
Gestão inapropriada dos resíduos & 45 & $9,36 \%$ \\
Desperdício de água & 44 & $9,15 \%$ \\
Rios poluídos & 41 & $8,52 \%$ \\
Doenças & 40 & $8,32 \%$ \\
Falta d'água & 36 & $7,48 \%$ \\
Desmatamento & 24 & $4,99 \%$ \\
Outros & 9 & $1,87 \%$ \\
\hline Total & $\mathbf{4 8 1}$ & $\mathbf{1 0 0 \%}$ \\
\hline
\end{tabular}

Fonte: Dados da Pesquisa (2020).

Como não está implementada a coleta seletiva no bairro, muitas pessoas optam por queimar os resíduos, prática que prejudica a qualidade de vida, devido a contaminação do ar. Além disso, também praticam o descarte nas ruas, que causa entupimento das saídas e impede o escoamento das águas e favorecendo enchentes.

Em relação a como consideram o ambiente do bairro (Figura 11), 17,09\% dos entrevistados acham que é organizado e 13,68\% que é limpo contra 18,80\% que afirmam que é mal cuidado e desorganizado. 
Figura 11 - Como você considera o ambiente do seu bairro.

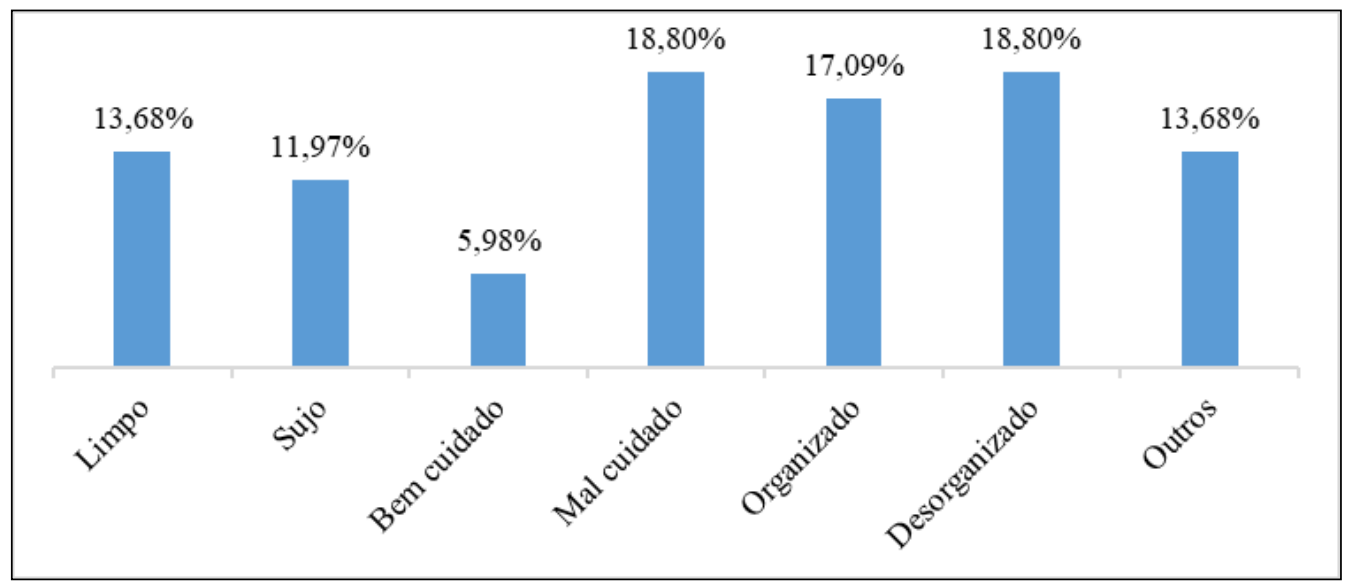

Fonte: Dados da Pesquisa (2020).

Frente a isso, ao serem questionados sobre a satisfação com as condiçóes do bairro, $46,15 \%$ responderam estar insatisfeitos com o local contra 50,43\% dos respondentes que consideram a qualidade de vida no bairro regular. Sobre a responsabilidade com a preservação do ambiente do bairro, $61,54 \%$ dos respondentes se consideram responsáveis pelo cuidado, o que demonstra a consciência de que tornar o ambiente do bairro limpo e organizado é responsabilidade de todos.

\subsection{Responsabilidade do Poder Público}

Pela Lei $\mathrm{n}^{\circ} 12.350 / 10$, os governos federal, estadual e municipais são responsáveis pela elaboração e implementaçáo dos planos de gestáo de resíduos sólidos e em vista disso, quando questionados se o poder público faz o suficiente para eliminar os resíduos sólidos urbanos (Figura 12), 52,99\% dos moradores acreditam que poderia ser feito mais, 21,37\% que não é feito e $12,82 \%$ que já é feito o suficiente.

O total de $52,99 \%$ dos moradores atribui os RSU jogados em locais inadequados ao fato do poder público não oferecer a coleta seletiva dos resíduos sólidos. De fato, se o poder público não agir para manter o bairro limpo oferecendo a coleta, os moradores acabam se livrando dos seus resíduos por meio do descarte em lugares inadequados.

Araújo e Pimentel (2016) identificaram que é preciso que o poder público elimine a possibilidade de ser descartado resíduos em locais inadequados e para que isso aconteça é necessário que sejam concebidas estratégias como limpeza e cercamento e, se cabível, a transformação em locais como praças, bosques, entre outros. 
Figura 12 - O poder público local faz o suficiente para eliminar o RSU.

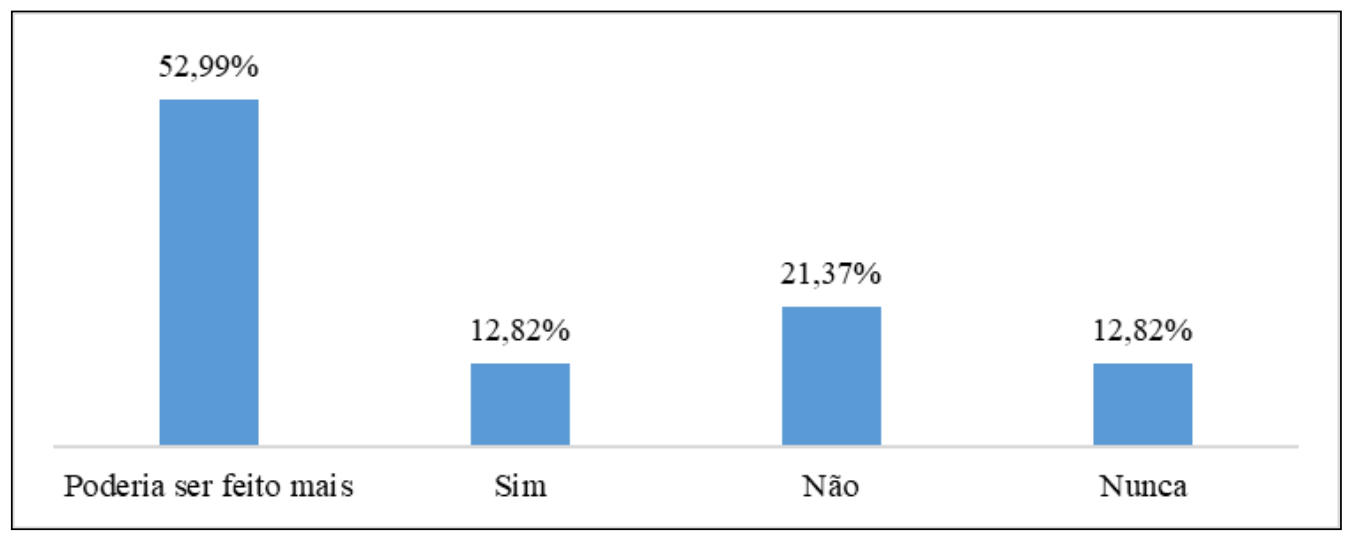

Fonte: Dados da Pesquisa (2020).

Quando questionado aos moradores quais RSU a coleta pública deveria recolher (Figura 13), 52,14\% dos respondentes acreditam que deve ser coletado todos os lixos que estiverem em volta da lixeira, $25,64 \%$ os lixos domésticos e $17,09 \%$ os entulhos dos terrenos baldios. É nítido que os moradores entendem que a responsabilidade é do poder público, mas que é necessário que os resíduos estejam separados e disponíveis para a coleta.

Figura 13 - O poder público local deve fazer a coleta de quais RSU.

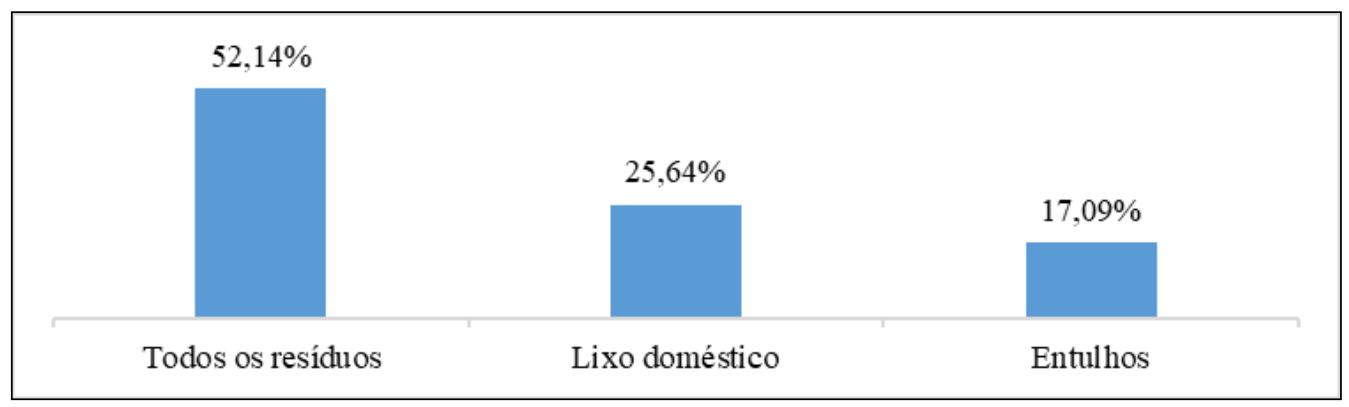

Fonte: Dados da Pesquisa (2020).

Quanto à percepção sobre a implementação de PP para os RSU, 64,96\% deles declarou que não existem políticas específicas para os RSU. É certo dizer que não existe nenhum projeto específico para os resíduos sólidos, já que por meio de conversas foi identificado que no bairro não existe coleta seletiva, e que todos os resíduos são encaminhados para o lixão.

Frente a isso, é importante que o poder público elabore ações voltadas para os RSU no bairro. O estudo realizado por Araújo e Pimentel (2016), e Tullio (2019) identificou que as políticas e a educação ambiental implantadas nos locais estudados ajudaram a melhorar o ambiente do bairro e a qualidade de vida dos moradores.

Sobre os canais de atendimento para reclamaçôes e denúncias sobre acúmulo de lixo em terrenos baldios e solicitação de limpeza dos mesmos (Figura 14), 42,74\% dos 
entrevistados disseram não saber se existe um canal, 23,93\% afirmou que as reclamaçóes e solicitaçóes podem ser feitas por telefone e 17,09\% que devem ser feitas pessoalmente na prefeitura. Cabe ressaltar que a prefeitura não soube informar se há um canal para atendimento ao público.

É de suma importância que o poder público divulgue amplamente a forma de solicitar serviços de limpeza ou denúncia de terrenos com depósito de resíduos, mas mesmo com um canal, $70,94 \%$ dos moradores relatam que o poder público náo toma nenhuma providência para evitar o descarte nos terrenos baldios nem realiza a limpeza nos locais.

Figura 14 - O poder público disponibiliza canal de atendimento para reclamaçóes, informaçóes ou para pedir uma limpeza em terrenos baldios?

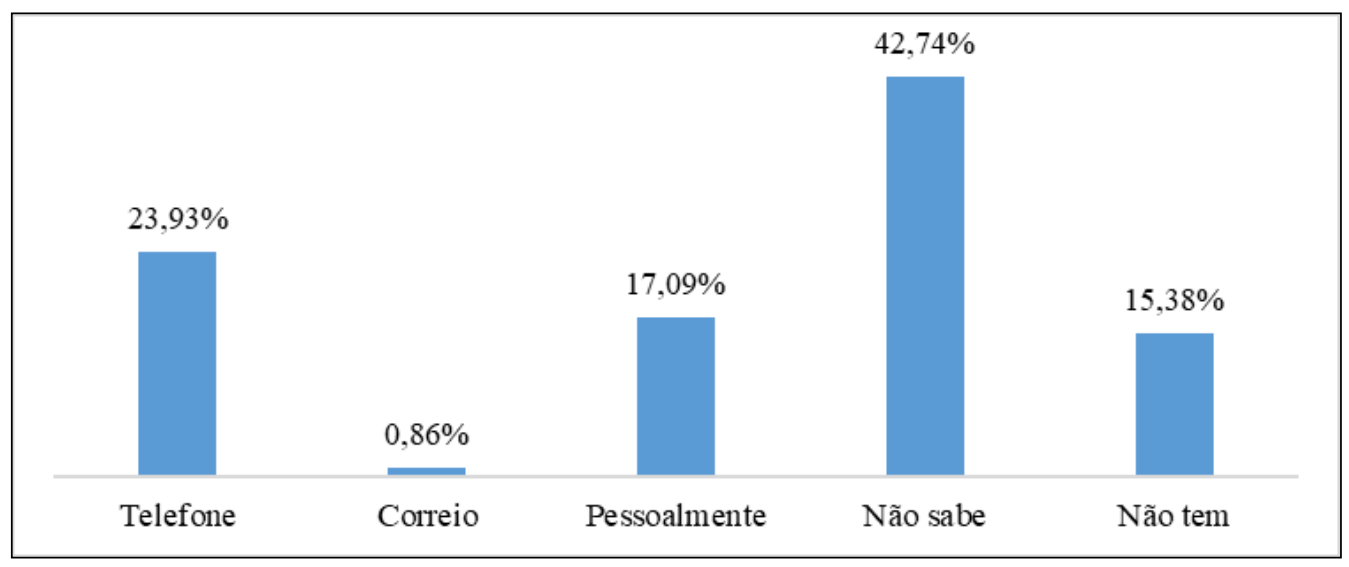

Fonte: Dados da Pesquisa (2020).

Sobre quais as soluçóes que o poder público pode empregar para evitar que a populaçáo faça o descarte nos terrenos baldios (Figura 15), 51,28\% dos moradores acreditam que a fiscalização e aplicação de multas sejam a solução, enquanto $15,38 \%$ acredita que seja necessário a disponibilizaçáo de local de descarte de entulho e apenas 15,38\% dos moradores acreditam que seja necessário o desenvolvimento de ações de EA.

O estudo realizado por Araújo e Pimentel (2016) em dois bairros de Maceió no estado de Alagoas apontou que açóes de EA, fiscalização e multa para aquele que descartar os resíduos em lugares inadequados, em conjunto com revitalização dos espaços ajudam a diminuir os pontos de descarte nos bairros. 
Figura 15 - Soluçôes que o poder público poderia usar para evitar descarte de resíduos em lugares inadequados.

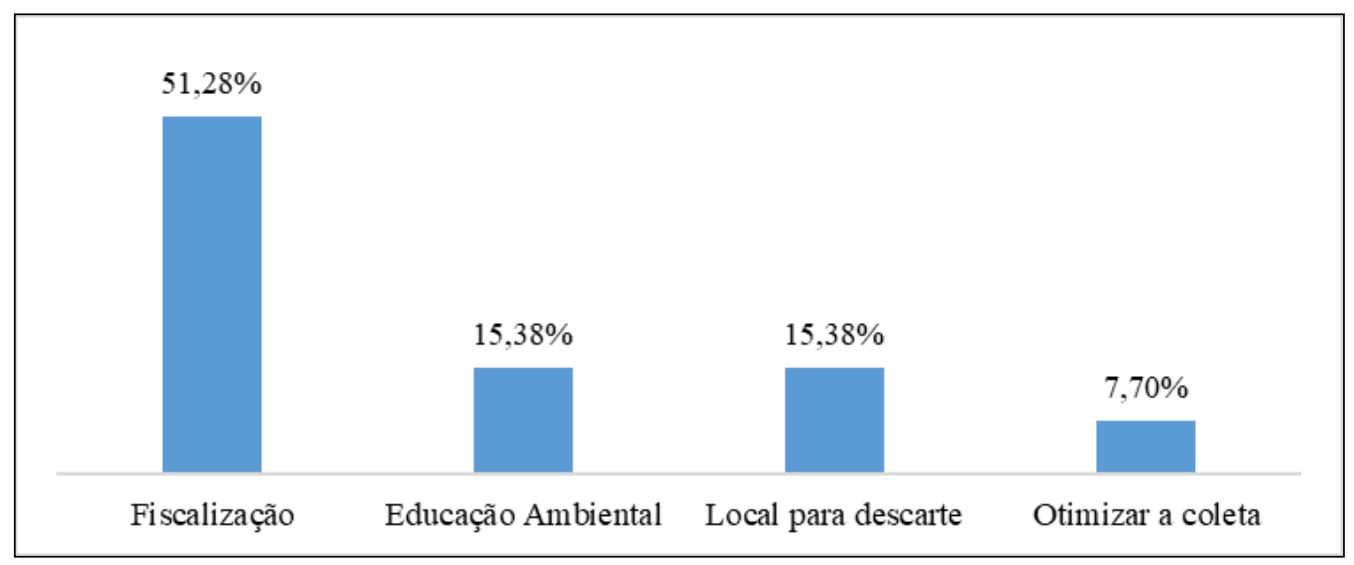

Fonte: Dados da Pesquisa (2020).

Em relação aos projetos de EA voltados para os resíduos sólidos no bairro, 39,31\% não soube responder, $21,37 \%$ apontou que não existe nenhum projeto e $12,82 \%$ afirmou que não existe nenhum interesse em desenvolver um projeto. Na percepçáo dos moradores, o poder público não tem interesse em cuidar do bairro, não dando muita atenção as necessidades do bairro.

Os estudos realizados por Mucelin e Bellini (2008) e Araújo e Pimentel (2016) demostraram que após a implementação dos projetos, houve grandes mudanças no bairro, deixando-os com um visual mais agradável, além de ajudar na qualidade de vida da população.

\subsection{Percepção Econômica em Relação aos Resíduos Sólidos Urbanos}

A partir do planejamento, melhoria na infraestrutura e um bom gerenciamento é possível minimizar os impactos negativos dos RSU nas cidades, ainda mais se estiverem alinhados com açóes educativas e de sensibilização quanto a mudança da cultura do consumismo. Com base nisso, foi questionado aos moradores, se em suas compras eles se preocupam em gerar menos lixo, e $58,97 \%$ dos respondentes afirmou que sim, citando que muitas vezes a compra é de apenas um pequeno item, não sendo necessário a utilizaçáo de sacolas plásticas, por exemplo.

Foi questionado se estariam dispostos a pagar por um produto mais caro se ele causasse menos danos ao meio ambiente (Figura 16), 42,73\% disse que sim, se isso pode ajudar na preservação do meio ambiente, eles pagariam a mais, $34,19 \%$ preferiu não responder, e $23,08 \%$ dos moradores afirmou que não mudaria. Nesse caso, é importante ressaltar que isso não depende apenas da intenção de ajudar na preservação do meio ambiente, mas também da renda familiar. 
Figura 16 - Você estaria disposto a pagar mais caro por um produto que causasse menos dano ao meio ambiente.

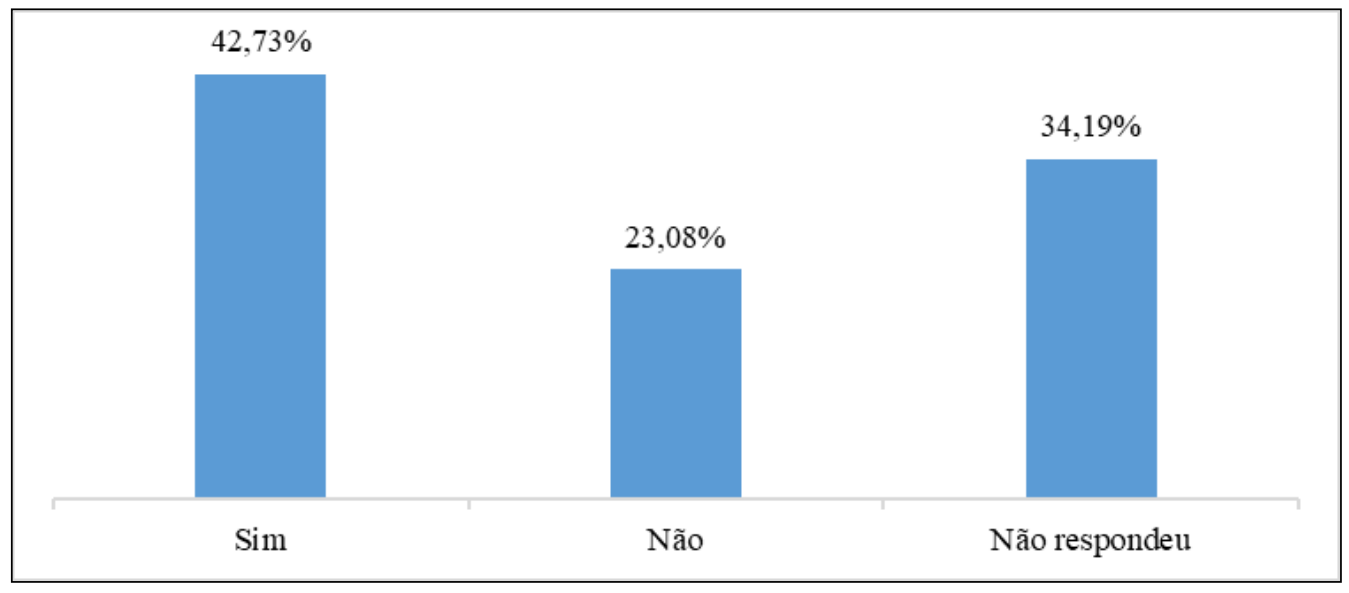

Fonte: Dados da Pesquisa (2020).

Assim, quando questionado aos moradores se eles já substituíram o consumo de um produto por outro similar, por ter um menor impacto ao meio ambiente, $29,91 \%$ disseram que sim, 34,19\% que não mudariam e 35,90\% não souberam responder.

É válido destacar que, a não mudança de um produto pode estar ligada a preferência, pois muitas vezes o consumidor se acostuma com uma determinada marca, ou acaba achando a qualidade de um produto melhor que o outro, mas ainda que nem todos os moradores estejam dispostos a trocar de produto, há um entendimento que pequenas atitudes podem trazer grandes benefícios ao meio ambiente e a qualidade de vida (BERTICELLI; PANDOLFO; KORF, 2017).

\section{CONSIDERAÇÓES FINAIS}

A partir da realizaçáo deste trabalho foi possível averiguar o conhecimento dos moradores do bairro Maracanã sobre o que são os resíduos sólidos urbanos (RSU) e quais problemas decorrem do mau gerenciamento desses resíduos, como o surgimento de doenças e poluição ambiental e visual.

Na percepção dos moradores, as melhores práticas para destinação dos RSU são a reciclagem e o aterro sanitário, entretanto, Barra do Bugres não tem local como estes para o descarte correto. Esse fator colabora com a percepção de que a falta de educação é o principal motivo para os descartes em locais impróprios e como resposta, os moradores acreditam que a melhor solução seja a fiscalização e multa ao indivíduo que não faça o descarte correto de seus resíduos.

A maioria dos entrevistados externou que o poder público não dá importância para o bairro e que mesmo após as denúncias não são tomadas providências para limpeza dos locais, além de afirmar que náo existe nenhuma política e projeto para os RSU no município 
de Barra do Bugres e que o poder público poderia fazer mais pela cidade referente a questão ambiental.

Diante dessa percepção, percebe-se a necessidade do desenvolvimento de PP voltadas ao desenvolvimento da infraestrutura e melhoria do gerenciamento dos RSU no bairro, como a implementação de ações de EA e criação de projetos de coleta seletiva e a construção de aterro sanitário. Além dessas medidas, a implantação de Ecopontos no bairro e em toda área urbana do município poderia amenizar os impactos gerados pelo descarte inadequado dos resíduos sólidos. Os munícipes teriam a possibilidade de dispor os resíduos que ainda não tem o destino correto.

Essas ações trazem benefícios em termos ambientais, sociais e econômicos e podem orientar os moradores na adoção de novos comportamentos, que auxiliam na melhoria da qualidade de vida e na preservação do meio ambiente.

\section{REFERÊNCIAS}

ABRELPE - Associação Brasileira de Empresas de Limpeza Pública e Resíduos Especiais. Panorama dos Resíduos Sólidos no Brasil 2016. Disponível em: https://abrelpe.org.br/ panorama/.

AGÊNCIA BRASIL. Saneamento e ranking da universalizaçáo do saneamento. Disponível em: http://agenciabrasil.ebc.com.br/geral/noticia/2019-06/no-brasil-85municipios-cumprem-todos-requisitos-de-saneamento-basico. Acesso em: 21 de outubro. 2019.

ARAÚJO, Kássia Karina; PIMENTEL, Angélica Kelly. A Problemática do Descarte Irregular dos Resíduos Sólidos Urbanos no Bairros Vergel do Lago e Jatiúca em Maceió, Alagoas. R. Gest. Sust. Ambient. v 4, n 2. Out 2015/mar 2016. Florianópolis.

\section{ASSOCIAÇÃO BRASILEIRA DE NORMAS TÉCNICAS. ABNT NBR 10004:}

Resíduos Sólidos - Classificação. Segunda edição. 31.05.2004, Rio de Janeiro - RJ. Disponível em: https://analiticaqmcresiduos.paginas.ufsc.br/files/2014/07/Nbr-100042004-Classificacao-De-Residuos-Solidos.pdf.

BARBOSA, Agoncilio Correia et al. Gestão pública e desenvolvimento sustentável: a importância da implantação de plano diretor no ato de criação de um município. Revista Cientifica da Ajes, v. 01, no 01 - Mai./Ago. de 2010. AJEA - Faculdades do Vale do Juruena, Juína-MT. Disponível em: https://www.revista.ajes.edu.br/index.php/rca/article/ view/62.

BARROS, Jessyca Rondon de. A Percepçáo Ambiental dos Moradores do Bairro CPA II Sobre os Resíduos Sólidos Urbanos. 2013. 37 f. Monografia (Graduação em Tecnologia em Gestão Ambiental). - IFMT, Cuiabá - MT. 
BERTICELLI, R.; PANDOLFO, A.; KORF, E. P. A gestão integrada de resíduos sólidos urbanos: perspectivas e desafios. Revista Gestáo \& Sustentabilidade Ambiental, Florianópolis, v. 5, n. 2, p. 711-744, out. 2016./mar. 2017. Disponível em: http://www. portaldeperiodicos.unisul.br/index.php/gestao_ambiental/article/view/3624.

BRASIL. Ministério do Desenvolvimento Regional - Agência Nacional de Águas e Saneamento Básico (ANA). Lei 11.445/07, estabelece as diretrizes nacionais para o saneamento básico e para a política federal de saneamento básico. Brasília, 5 de jan. 2007.

BRASIL. Ministério do Meio Ambiente. Lei 9.605/98, Dispóe sobre as sançóes penais e administrativas derivadas de condutas e atividades lesivas ao meio ambiente, e dá outras providências. Brasília, 12 de fevereiro de 1998.

BRASIL. Ministério do Meio Ambiente. Lei 9.795, de 27/04/1999, dispõe sobre a educação ambiental, institui a Política Nacional de Educação Ambiental e dá outras providências. Brasília, 27 de abril de 1999.

BRASIL. Ministério do Meio Ambiente. Lei no 12.305/10, que institui a Política Nacional de Resíduos Sólidos (PNRS). Diário Oficial da União, Brasília, 2 de agosto de 2010 .

CAZAROTO, R. B. et al. Percepção Ambiental dos Alunos de Ensino Médio E.E. "Emílio Oscar Hülle" - Município de Marechal Floriano - Espírito Santo. Revista Eletrônica Debates em Educação Científica e Tecnológica, V. 2, N. 02, p. 1321 Dezembro, 2012. Disponível em: https://ojs.ifes.edu.br/index.php/dect/article/ view/32/26. Acesso em 10 nov. 2019.

FERNANDES, R.S. et al. Uso da percepção ambiental como instrumento de gestão em aplicação ligadas ás áreas educacional, social e ambiental. In: II Encontro da ANPPAS, Campinas, São Paulo, 2004. Acesso em: 26 de outubro.2019.

GIL, A. C. Como elaborar projetos de pesquisa. 5. ed. São Paulo: Atlas, 2010.

HEGEL, C. G. Z.; Cornélio, P. F. O. Resíduos Sólidos Urbanos: Depósitos Irregulares no Munícipio de Passo Fundo, Rio Grande do Sul, Brasil. Revista Gestáo \&

Sustentabilidade, Florianópolis, v. 2, n.1, p. 5-19, abr./set. 2013. Disponível em: http:// www.portaldeperiodicos.unisul.br/index.php/gestao_ambiental/article/view/1215/1099. Acesso em: 21 outubro 2019.

HEMPE, Cléa; Nogueira, Jorge Orlando Cuellar. A Educação Ambiental e os Resíduos Sólidos Urbanos. Revista Eletrônica em Gestáo, Educação e Tecnologia Ambiental, v 5, n 5, p. 682-695, 2012. Disponível em: https://periodicos.ufsm.br/reget/article/ view/4117/2798. 
IBGE. Estimativa populacional de Barra do Bugres/ MT em 2019. Disponível em: https://cidades.ibge.gov.br/brasil/mt/barra-do-bugres/panorama. Acesso em: 21 de out. 2019.

IBGE. Estimativa populacional em 2016. Disponível em: http://www.cidades.ibge.gov. $\mathrm{br} /$ xtras/perfil.php?lang=\&codmun=510795\&search=mato-grosso. Acesso em: $21 \mathrm{de}$ out. 2019.

IBGE. Pesquisa Nacional de Saneamento Básico 2008. Rio de Janeiro: IBGE, 2010. Disponível em: https://biblioteca.ibge.gov.br/visualizacao/livros/liv45351.pdf.

JUNK, W. J.; CUNHA, C. N.; WANTZEN, K. M.; PETERMANN, P.; STRUSSMANN, C.; MARQUES, M. I.; ADIS, J. Biodiversity and its conservation in the Pantanal of Mato Grosso, Brazil. Aquatic Sciences, v. 68, p. 278-309, 2006. Disponível em: http:// www.eventus.com.br/atbc2012/BiodiversityPantanal_MT.pdf. Acesso em: 02 de out. 2020.

LEME, S. M. Comportamento da População Urbana no Manejo dos Resíduos sólidos Domiciliares em Aquidauana - MS. Geografia, v. 18, n. 1, p.157-192, 2009. Disponível em: http://www.uel.br/revistas/uel/index.php/geografia/article/viewFile/2392/226 6. Acesso em: 27 de out. 2019.

LIMA, Eliana Beatriz Nunes Rondon; Filho, Paulo Modesto e Moura, Rubem Mauro Palma de. (Orgs.). Plano Municipal de Saneamento Básico: Barra do Bugres-MT. Cuiabá-MT: EdUFMT, 2017. Disponível em: http://pmsb106.ic.ufmt.br/wp-content/ uploads/2018/04/ PMSB_Barra-do-Bugres.pdf.

LOPES, H. R. R. Avaliação da Política Nacional de Resíduos Sólidos e modelagem de um processo para elaboração de planos municipais simplificados de gestão integrada de resíduos sólidos. Dissertaçáo [Mestrado em Políticas Públicas]. Instituto de Pesquisa Econômica Aplicada (IPEA, Brasília, 2016. Disponível em: https://www.ipea.gov.br/sites/ images/ mestrado/turma2/huanderson-ritchelly.pdf.

MAGALHÃES, Loiva Zanon; WERLE, Hugo Scheuer. Problemas ambientais de uma cidade média de Mato Grosso: o caso de Barra do Bugres. Planejamento e Políticas Públicas, n. 33, 2009. Disponível em: https:/www.ipea.gov.br/ppp/index.php/PPP/ article/view/154/ 169.

MARCONI, M. A.; LAKATOS, E. M. Fundamentos de metodologia científica. 8. ed. São Paulo: Atlas, 2017.

MELAZZO et al. Políticas públicas e exclusão social: a construção do debate no interior do SIMESPP. Anais do IV Fórum de Ciências da FCT/UNESP, Presidente Prudente SP, 15 a 17de maio de 2003. Disponível em: http://www.prudente.unesp.br/simespp/ prodcient.html. 
MORAIS, Eduarda Katiane Albino, et al. Análise da Percepção Ambiental sobre a Geração de Resíduos Sólidos Urbanos dos Moradores do Bairro Jardim Tarumã no Município de Tangará da Serra - MT. Anais do $1^{\circ}$ Congresso Sul Americano de Resíduos Sólidos e Sustentabilidade, 2018, Gramado - RS. Disponível em: http://www.ibeas.org. $\mathrm{br} /$ conresol/conresol2018/IV-043.pdf.

MUCELIN, Carlos Alberto; BELLINI, Marta. Lixo e impactos ambientais perceptíveis no ecossistema urbano. Revista Sociedade e natureza (Online) vol.20 no. 1, pág. 111 124, jun. 2008. Disponível em: https://www.scielo.br/pdf/sn/v20n1/a08v20n1.

PLANO NACIONAL DE RESÍDUOS SÓLIDOS. Versáo Preliminar para Consulta Pública. Brasília, 2011. Disponível em: https://www.mma.gov.br/estruturas/253/_ arquivos/versao_preliminar_pnrs_wm_253.pdf.

\section{FUNDAÇÃO OSWALDO CRUZ - FIOCRUZ. Políticas Públicas e Modelos de}

Atençáo e Gestão à Saúde. Data de publicação: 02/05/2018. Disponível em: https:// portal.fiocruz.br/politicas-publicas-e-modelos-de-atencao-saude.

LUPPI, Lierge; SILVA, Paula Maines da; ARANTES, Iolanda Barbosa. Gestão de Resíduos Sólidos Urbanos: Estudo de Caso do Aterro Sanitário de Tangará Da Serra/ MT e a Adequação da Lei 12.305. Anais do XXI ENGEMA - Encontro Internacional sobre Gestão Empresarial e Meio Ambiente. Dezembro, 2019. Disponível em: http:// engemausp.submissao.com.br/21/anais/arquivos/111.pdf.

VERAS JUNIOR et al. O Plano de Gerenciamento Municipal Integrado de Resíduos Sólidos nos Ecopontos em Fortaleza. PAULO SÉRGIO VERAS JUNIOR; Adriana Teixeira Bastos; Cláudio César Torquato Rocha; Tiago André Portela Martins. Anais do XXI ENGEMA - Encontro Internacional sobre Gestáo Empresarial e Meio Ambiente. Dezembro, 2019. Disponível em: http://engemausp.submissao.com.br/21/anais/ arquivos/96.pdf.

QUERINO, Luana Andrade Lima. Percepçáo Ambiental Acerca dos Resíduos Sólidos Domiciliares: um estudo com os moradores de Sáo Sebastiáo de Lagoa de Roça PB. 2015. 78 f. Dissertação (Pós-Graduação em Recursos Naturais) - UFCG, Campina Grande - PB. Disponível em: http://dspace.sti.ufcg.edu.br:8080/jspui/handle/riufcg/982.

RABÊLO, Olivan da Silva. Proposta Estratégica para o Acondicionamento dos Resíduos Sólidos em Barra Do Bugres-MT: Usina de Reciclagem. Ministério da Educação - UFMT, 2013. Disponível em: http://docplayer.com.br/15872477-Propostaestrategica-para-o-acondicionamento-dos-residuos-solidos-em-barra-do-bugres-mt-usinade-reciclagem.html.

RICHARDSON, R. J. et al. Pesquisa social: métodos e técnicas. 3. ed. São Paulo: Atlas, 2007. 
SILVA, A.C.R. Metodologia da pesquisa aplicada à contabilidade: orientaçóes de estudos, projetos, artigos, relatórios, monografias, dissertaçóes, teses. Antônio Carlos Ribeiro da Silva. - 3. Ed. - São Paulo: Atlas, 2010. Disponível em: https://repositorio. ufba.br/ri/bitstream/ri/24428/1/eBook_Metodologia_da_Pesquisa_Aplicada_a_ Contabilidade-Ci\%C3\%AAncias_Contabeis_UFBA.pdf.

SOARES, L. M. P. Influência de diferentes doses de compostos produzidos no sistema de tratamento descentralizado de resíduos sólidos orgânicos domiciliares para o desenvolvimento de tomateiro. (Lycopersicum esculentum). 2012. . Monografia de Licenciatura Plena em Ciências Biológicas da Universidade Estadual da Paraíba. Campina Grande/PB, 2012.

SUESS, R. C. et al. Percepção Ambiental de Diferentes Atores Sociais Sobre o Lago do Abreu em Formosa - GO. HOLOS, Ano 29, Vol. 6. 2013. Disponível em: https:// www2.ifrn.edu.br/ojs/index.php/HOLOS/article/view/1287/771. Acesso em: 10 nov. 2019.

TROTTA, P. A gestão de resíduos sólidos urbanos em Portugal. In: VII Congresso Nacional de Excelência em Gestão. 2011, Rio de Janeiro. Anais do VII Congresso Nacional de Excelência em Gestão. Rio de Janeiro, 2011. Disponível em: https://www. inovarse.org/sites/default/files/T11_0350_2173_7.pdf.

ZANI, H.; ASSINE, M. L.; SILVA. A. Batimetria fluvial estimada com dados orbitais: estudo de caso no alto curso do rio Paraguai com sensor ASTER. Revista Geociências (Unesp) v. 27, n. 4, p. 555-565, 2008. Disponível em: https://www.periodicos. rc.biblioteca.unesp.br/ index.php/geociencias/article/view/3500.

ZANTA, V. M; FERREIRA, C. F. A. Gerenciamento Integrado de Resíduos Sólidos Urbanos. In: Resíduos Sólidos Urbanos: Aterro Sustentável para municípios de pequeno porte. Rio de Janeiro. ABES, RIMA. p.1-16. 2003. 